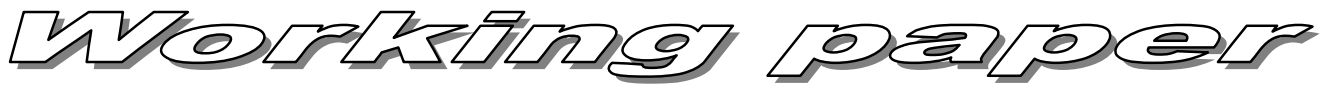 wint
}

No. 71

\author{
Michal Bauer \\ Theory of the Firm under Uncertainty:
}

Financing, Attitude to Risk and Output Behavior
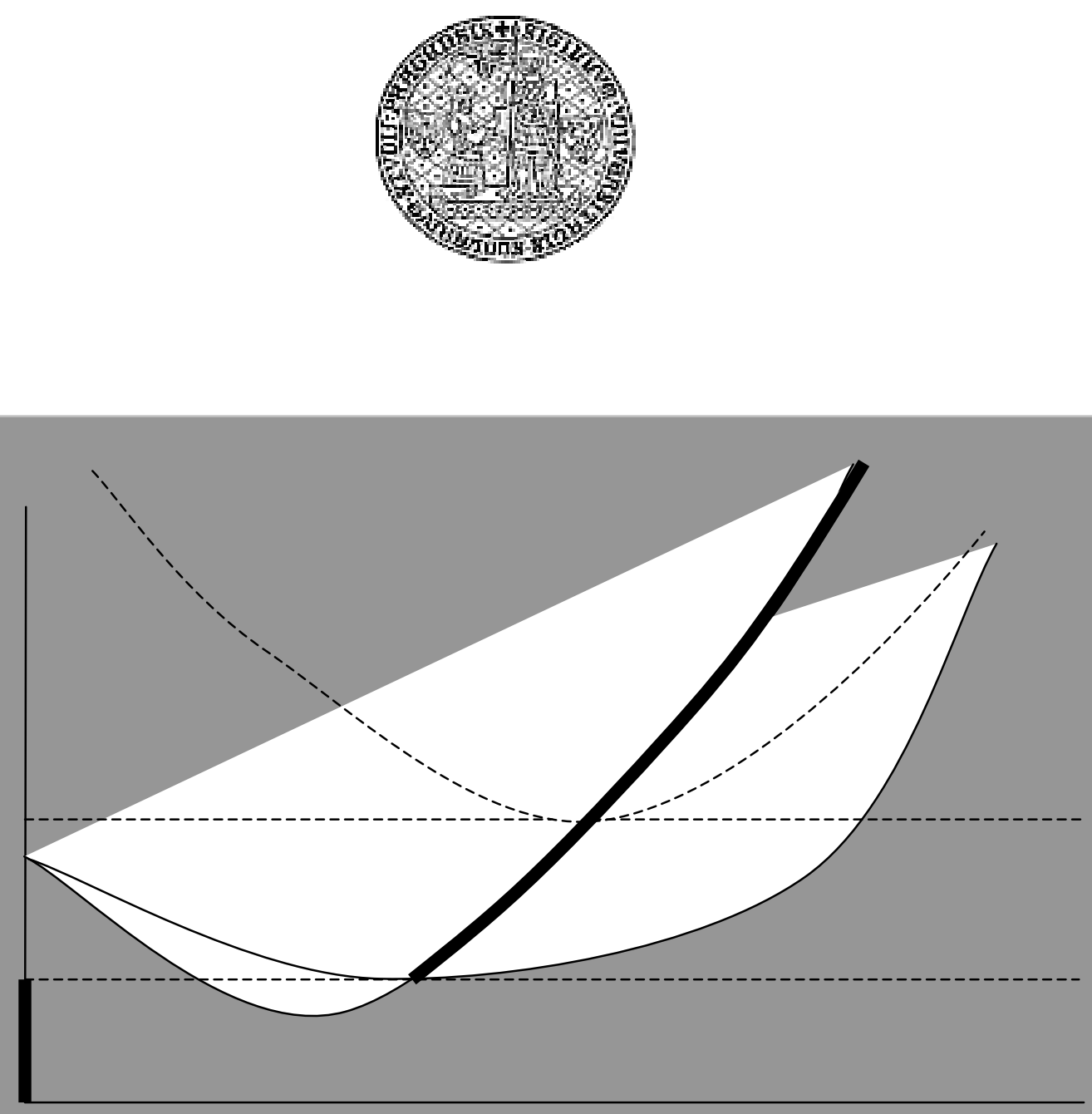
Disclaimer: The IES Working Papers is an online, peer-reviewed journal for work by the faculty and students of the Institute of Economic Studies, Faculty of Social Sciences, Charles University in Prague, Czech Republic. The papers are blind peer reviewed, but they are NOT edited or formatted by the editors. The views expressed in documents served by this site do not reflect the views of the IES or any other Charles University Department. They are the sole property of the respective authors. Additional info at: ies@fsv.cuni.cz

Copyright Notice: Although all documents published by the IES are provided without charge, they are only licensed for personal, academic or educational use. All rights are reserved by the authors.

Citations: All references to documents served by this site must be appropriately cited. Guidelines for the citation of electronic documents can be found on the APA's website: http://www.apa.org/journals/webref.html.

\title{
THEORY OF THE FIRM UNDER UNCERTAINTY: \\ Financing, Attitude to Risk and Output Behavior
}

MICHAL BAUER

\begin{abstract}
The paper examines the risk behavior of a competitive firm under price uncertainty. In the model developed in the paper we have departed from the thought-provoking approach of Greenwald and Stiglitz (1993a), which implies solely risk averse behavior of firms due to its restrictive assumptions about firm's financing. Through the incorporation of other plausible and more general assumptions about the firm's financing (namely the access to the equity market, possible existence of soft budget constraint) we were able to theoretically formulate the conditions, under which the firm is induced to behave in more risk averse vs. risky manner. While the firm's attitude to risk directly influences its willingness to produce, our results indicate that in the environment of uncertainty the price and technology are not the only important determinants of the firm's optimal output level as is the case for the neoclassical theory of firm. The results of our model have shown that additional factors like firm's net worth position, sensitivity of managers to bankruptcy, firm's ability to raise new equity, softness of the budget constraint and degree of uncertainty about the future prices may play an important role for firm's optimal output considerations.
\end{abstract}

JEL Classification: D21, D81, G32.

Keywords: firm, uncertainty, attitude to risk, capital structure, soft budget constraint. 


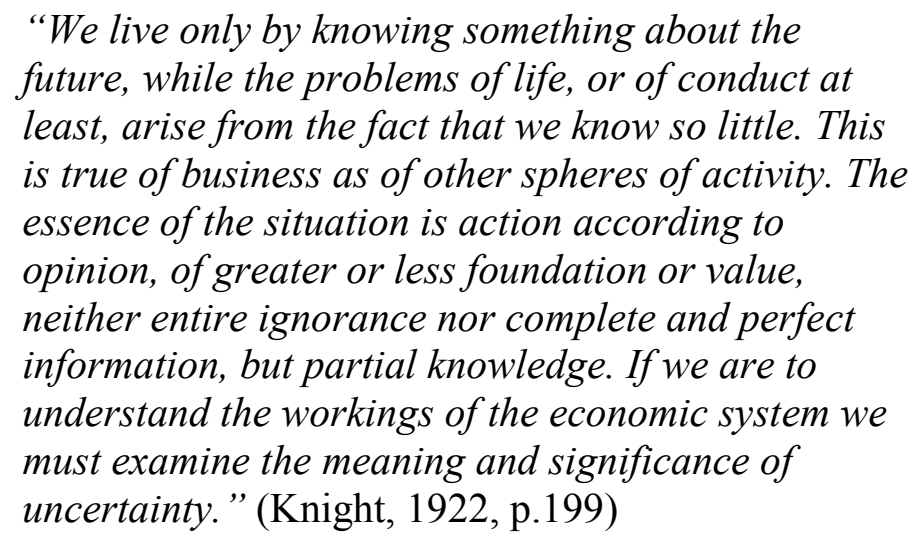

In the previous decades there is clear tendency in the economic literature to remove the traditional assumption in the theory of firm, which says, that the demand for the products is known with certainty at the time when the output decision is made. The uncertain character of environment in which the firm has to operate has become a critical component in the theories of firm. It was shown on number of places (e.g. Sandmo, 1971, Leland, 1972) that firm's attitude to bear the inherent risk of production has important effects on the firm's willingness to produce, i.e. on its choice of optimal level of production. However, these older papers (and also the contemporary microeconomic textbooks, e.g. Gravelle and Rees, 1992) take the attitude to risk as an exogenous characteristic associated with production "black box" called firm. In compliance with the recent development of new institutional understanding of firm it is hardly acceptable to consider the firm as an individual with simple utility function.

There are number of more recent papers, which relate the firm's attitude to risk with the financing considerations. In fact, they use the following logical framework for explaining the firm's risk behavior: financing $\rightarrow$ attitude to risk $\rightarrow$ optimal level of output. The New Keynesians (Greenwald and Stiglitz, 1993a) base their theory of risk-averse firm on asymmetric information between managers and capital providers, which in their models of firm leads to the firm's reliance on the usage of debt related with bankruptcy risk. Their theory of risk-averse firm is a key ingredient in New Keynesian economics when explaining the existence of long-lasting business cycles in the economy.

The risk-seeking behavior of firms resulting from too easy access to debt-financing from the state-owned banks (soft budget constraint), which lead to the extensive accumulation of bad loans, was a central policy issue in the transition economies (Kornai, Maskin and Roland, 2003). The collapse of the banking sector in Asia in 1990s can be usefully thought in terms of the over-risky behavior and soft budget constraint as well (Krugman, 1998).

However, in all these papers the concept of firm under uncertainty is a part of the model with the primer focus to explain certain phenomena on the macroeconomic level (business cycles, troubles of the banking sector in the transition countries, the nature of the Asian crises). Although they capture important patterns of firm's risk behavior, we will attempt to show, that they focus rather on the specific types of constraints or conditions of firm's financing. As a result they do not provide a complete picture of the determinants of the firm's attitude to risk and thus optimal output level under uncertainty. This is the gap this paper will aim to tackle. 
The aim of paper is to develop a comprehensive model of firm, which would include all the important parameters, which influence, if the firm behaves in risk averse, risk neutral or riskseeking manner. In this way we will incorporate additional determinants for the firm's decision-making about optimal output, which are based on the uncertain character of the environment.

At the beginning of the paper we will conceptually clarify the term uncertainty and we will briefly evaluate the existing theories of firm from perspective of our major question: What are the major determinants of the firm's attitude to risk and therefore of the firm's willingness to produce under uncertainty? Consequently, we will construct a new model of firm departing from Greenwald and Stiglitz (1993a), but free of limitations identified in the comparative section of the paper. We will argue that changes in financing (net worth position, possibility to raise new equity, softness of the budget constraint) and the perception of risk faced by firm can explain all types of attitude to risk (risk averse, risk neutral and risk-seeking behavior) and can potentially have large effects on the optimal output level.

\section{2) Uncertainty and its sources: Firm's perspective}

Before we start to deal with the theory of firm and build our model let's clarify the term uncertainty, attitude to risk and point out on possible sources of risk, because the understanding of these issues is often ambiguous for different streams of thoughts.

In the economic literature we can identify two different distinctions in this respect. Firstly, Dosi and Edigi (1991) in analogy to Herbert Simon propose procedural and substantive uncertainty. Substantive uncertainty results from "the lack of all the information which would be necessary to make decisions with certain outcomes." On the other hand, the procedural uncertainty arises from "limitations on the computational and cognitive capabilities of the agents to pursue unambiguously their objectives, given the available information" (Dosi and Edigi, 1991, p. 145).

Secondly, Dequech (1997) draws the dividing line between weak and strong, substantive uncertainty. Strong uncertainty, in contrast to weak uncertainty (Knightian risk) is characterized by the absence of unique and fully reliable probability distributions. The individual is not viewed as capable of having probability distribution functions over a set of possible outcomes. This strong or fundamental uncertainty (Knightian uncertainty) is connected with non-predetermined structural change and creativity. The list of possible events is not predetermined or knowable ex ante and is yet to be created.

The aim of the paper is to investigate into the systemic determinants of attitude to risk, not to base explanations on structural changes, because it is something from definition hardly explainable. At the same moment, time and uncertainty is an integral part of economic reality and omitting these facts is like play Hamlet without Hamlet. In our paper we will focus on a firm, which is able to optimize or tries to. The general playground for our rational firm will be weak substantive uncertainty (probabilistic approach). The following are the major reasons.

Firstly, while even the weak form of uncertainty has significant effects on behavior firm, there is no need to go towards stronger uncertainty. We would lose some of the principal tools of economics and the desired results would lose some of its clarity once we would attempt to employ fundamental or procedural uncertainty. As Maskin and Tirole (1999, p. 106) point out, the economists made only a little progress towards modeling bounded rationality based on stronger types of uncertainty. 
Secondly, and probably more importantly, the time horizon in firm's decision-making is not so long so that the decision-makers would have to include into their considerations fundamental changes in environment. In other words, in reality weak and strong type of uncertainty are present in parallel and each is more relevant for the analysis of different situations. In our opinion the probabilistic one plays a major role in firm's decision-making although the relative weights might be different for the analysis of, for example, the economic history with longer time horizon.

Let's also define different attitudes to risk. If the decision-maker (e.g. firm) values the uncertain outcomes by their expected values, than we consider it as risk-neutral. If the uncertain outcomes are valued less than is their expected value, than we say the firm is risk averse. The risk averse firm takes the uncertainty as a harmful thing and associates additional "costs" to uncertainty. On the other hand, risk-seeking firm prefers the uncertain outcomes to its expected value. Such a firm considers the uncertainty as a beneficial feature of the environment.

The interplay between uncertainty related to the productive activity of firms and financing arises from a simple fact: most production takes time. The cost of investment or inputs must be incurred before the revenue is obtained from the sale of its output. This implies that every production plan must be accompanied by financing considerations (Magill, 1996). The reason of this is the fact, that uncertainty about the future has not lead to a trading system with very complex long term commitments, but to a trading system of repeated sequential trading using much simpler short-term contracts that allow agents to make commitments as information reveals. Production in general takes time so that firms need to make detailed forward plans for the supply of commodities without the benefit of forward commitments to buy on the part of consumers. In fact, the firms face incomplete markets as there are no future markets for their products. This trading system imposes a risk on the decision making of a firm.

As a consequence there are two types of contracts within a firm (Magill, 1996):

- those which are used for organizing (coordinating) production activity and

- those which are used for transferring (redistributing) income over time and across unforeseen events.

The first category includes all the supply and delivery contracts signed between firms, between firms and government, and between firms and individuals, as well as contracts between firms and employees. These contracts are necessary for running a firm, but every such contract imposes a risk on a firm. However, as such it does not solve the uncertainty in contrary to the second type of contracts. The second type includes mainly lending contracts (bonds) and equity contracts, in general the contracts with capital providers. The firm transfers the financial risk coming from the first type of contracts on providers of financing, because the firm as such is a legal abstraction. Therefore we will focus on the interface between the firm represented by managers and capital providers in our search for the determinants of attitude to risk and firm's output behavior.

\section{3) Existing concepts of firm behavior under uncertainty in a nutshell}

This section should, firstly, provide us a brief overview of the existing concepts of firms which are of the highest relevance for our core question and from which we will depart from when constructing the model and secondly, endow us with a justification for the assumptions we will use in section 4). 


\section{a. Standard theory of firm under uncertainty with assumed risk aversion}

The traditional neoclassical theory base the behavior of firm solely on the simple valuation maximization principle. Firms are assumed to either operate in uncertainty-free environment, because there is not aspect of time, or the firm behavior is not affected by uncertainty, because firms are assumed to be risk-neutral. The optimal output level is chosen so as to satisfy the equality of marginal costs of production and price of output.

The first theoretical stream, which systematically examined the effects of output price uncertainty on production decisions of firms, is usually called standard theory of firm under uncertainty (Sandmo, 1971, Coes, 1977, Quiggin, 2001, Hau, 2003). It removes the traditional neoclassical assumption that the demand for products is known with certainty at the time when output decision is made. This assumption is usually embodied in the objective function of firm, which maximizes the expected profits. These authors do not consider this assumption as satisfactory as it completely rules out risk averse behavior. Instead, it is assumed that firm's attitude towards risk can be summarized by a von Neumann-Morgenstern utility function, which, beside other properties, is increasing in profit $v^{\prime}(\pi)>0$ and marginal utility of profit is decreasing in profit $v^{\prime \prime}(\pi)<0$. The firm is therefore assumed to be risk averse. ${ }^{1}$

The firm chooses output to maximize

MAX $E v\left(\pi^{i}\right)=p^{i}-(1+r) c\left(q^{i}\right)$, where $\pi^{i}$ is uncertain profit of the firm (or owner's income), $c\left(q^{i}\right)$ are firm's costs of production, $q^{i}$ is an output level, $p^{i, E}$ is the expected price (usually taken as mean price) and $r$ is interest rate representing the opportunity costs of production.

The results after the optimality exercise are the following:

$$
E v^{\prime}\left(\pi^{i}\right)\left[p^{i, E}-(1+r) c^{\prime}\left(q_{r-a}^{*}\right)\right]+\operatorname{cov}\left[v^{\prime}\left(\pi^{i}\right), p^{i}\right]=0 .
$$

For a risk neutral firm the covariance item will be equal to zero, because marginal utility would remain constant independently on the development of uncertain price (and thus profit). Therefore, the risk-neutral firm chooses the optimal output at the level, which equalizes the expected price and present value of marginal costs. If the expected price is taken as equal to the mean price, the level of output that would be produced by the risk neutral producer facing price uncertainty is the same as the level of output under price certainty.

In the standard theory of firm under uncertainty the firm is assumed to be risk averse. As a consequence the firm will have negative covariance between the marginal utility of owner's income, because increased price will decrease marginal utility of income. Hence the difference between expected price and present value of marginal costs must be positive. Since it is assumed that marginal costs are increasing this implies that the optimal output is smaller than for risk neutral firm.

The principal result of this concept is the demonstration that 1) optimal output for risk averse firm is less facing an uncertain demand than it would be in case the firm faced certain price of

${ }^{1}$ This shift from expected profit in theory of firm to the expected utility of profit very much resembles the shift in consumer theory from expected value to expected utility originally suggested by Daniel Bernoulli almost three centuries ago via his so called Petersburg's paradox. 
the same expected value or if the firm were risk neutral and 2) with more risky distribution of prices (stretching of the probability distribution around constant mean) the risk averse firm reduces output.

These concepts thus clearly demonstrate that the attitude to risk has significant impact on the firm's behavior. However, this concept has also several weaknesses. It keeps the "black-box" approach of modeling firm as a production set with aversion to risk. Already Sandmo (1971, p.73) pointed out that "The firm makes its output decisions with sole regard for short-run profits and does not consider the relationship between this output policy and long-run policies for investment and finance. In a sense, it is a weakness of the model that it takes no account of this interrelatedness... Investment and financing decisions can hardly be given adequate treatment in the present framework" The standard model of firm under uncertainty does not attempt to explain the aversion to risk, it simple assumes its existence and as consequence firm produces less ${ }^{2}$.

The aim of the paper is to find determinants of the firm's aversion to risk, which influences the willingness to produce. In this respect this type of models gives hardly any clue. Therefore, we will make another step and we will trace the relationship between financing and attitude to risk.

\section{b. New Keynesians}

For the New Keynesians ${ }^{3}$ represented by Greenwald and Stiglitz an explicit theory of capital structure is a central issue for the firm behavior and its attitude to risk. Greenwald and Stiglitz consider the manager's decision-making between debt and equity as closely related to information asymmetries on the capital market and they use the signaling argument for financing decisions of firm.

With equity, the firm shares risk with those who provide finance and the firm has no fixed obligation to repay. But debt is unforgiving if things go poorly. Failure to make the fixed payments on time thus results in bankruptcy. The fact that significant proportion of the firm's capital is usually financed by debt in spite of the seeming advantages of equity is explained by asymmetric information between the firm issuing the shares and the investors which consider the issuing of the new shares as negative signal due to the lack of information. Therefore, the market value of the firm will tend to decline.

Moreover, those who know that the market overvalues their shares are supposed to be the most anxious to sell additional shares. Issuing equity is thus treated as a negative signal and the equity market cannot be considered as equally possible source of financing. Just as in the famous lemon's market of Akerlof (1970), adverse selection preclude any trade and the equity market thus "may break down or be severely limited" (Greenwald and Stiglitz, 1990, p.160). (2005).

${ }^{2}$ For more details and references on further development of this stream see Bauer

${ }^{3}$ The detailed delimitation of New Keynesians from other streams of Keynesians, which will be respected also in this paper, can be found in Greenwald and Stiglitz (1987, 1993). Another important representatives to this line of research is, for example, Ackerloff and Yellen (1985). 
As consequence of this extreme approach towards the possibility of equity financing the New Keynesians claim that firms will tend to be strongly risk averse, because they do not have access to equity finance and are therefore pushed to debt finance with fixed repayments. In their models (see below) of firm behavior if firms want to obtain more capital, to invest or to increase production, they must borrow the finance and thus expose themselves to a considerable risk, including the risk of bankruptcy.

Theory of risk averse firm

Now we will turn our attention to the question, how (based on the signaling argument) according to Greenwald and Stiglitz (1993a) risk considerations affect firms' production decisions. The firm cannot raise equity and it is financed by debt. The debt imposes on the firm risk of bankruptcy and there are personal costs for managers related to bankruptcy. Their value and reputation on the managers' market may be harmed, because it is usually not possible to distinguish, if the bankruptcy is caused by bad management or adverse market conditions. Firms thus take the bankruptcy costs into account in their production decisions.

The principal result of their model ${ }^{4}$ is following:

$\frac{P_{t}^{i, E}}{P_{t}^{E}}=1=\left(1+r_{t}\right) c^{\prime}\left(q_{t, B}^{i^{*}}\right)+\rho_{t}^{i}$,

where $\rho_{t}^{i}$ equals real marginal costs of bankruptcy and $q_{t, B}^{i^{*}}$ is the optimal output for Greenwald and Stiglitz's bond-financed firm. With debt there is the probability of bankruptcy and with positive probability of bankruptcy there are positive bankruptcy costs (risk premium, $\rho_{t}^{i}$ ). As the firm is assumed to have increasing marginal costs, the level of optimal output $q_{t, B}^{i^{*}}$ is lower than the one associated with the neoclassical firm $q^{i^{*}}$ neoclassical. Under certainty there would be no probability of bankruptcy, no risk premium and the firm would produce more. As the extremely high level of bond-financing is assumed, the resulting risk premium $\rho_{t}^{i}$ is also extremely high making the firm very extensively risk averse and producing correspondingly low level of production.

The Chart 1 illustrates graphically the logic we have just explained.

${ }^{4}$ The equation has slightly different notation than in the original paper in order to be compatible with other concepts explained in this paper. 


\section{Chart 1. Greenwald and Stiglitz's firm supply}

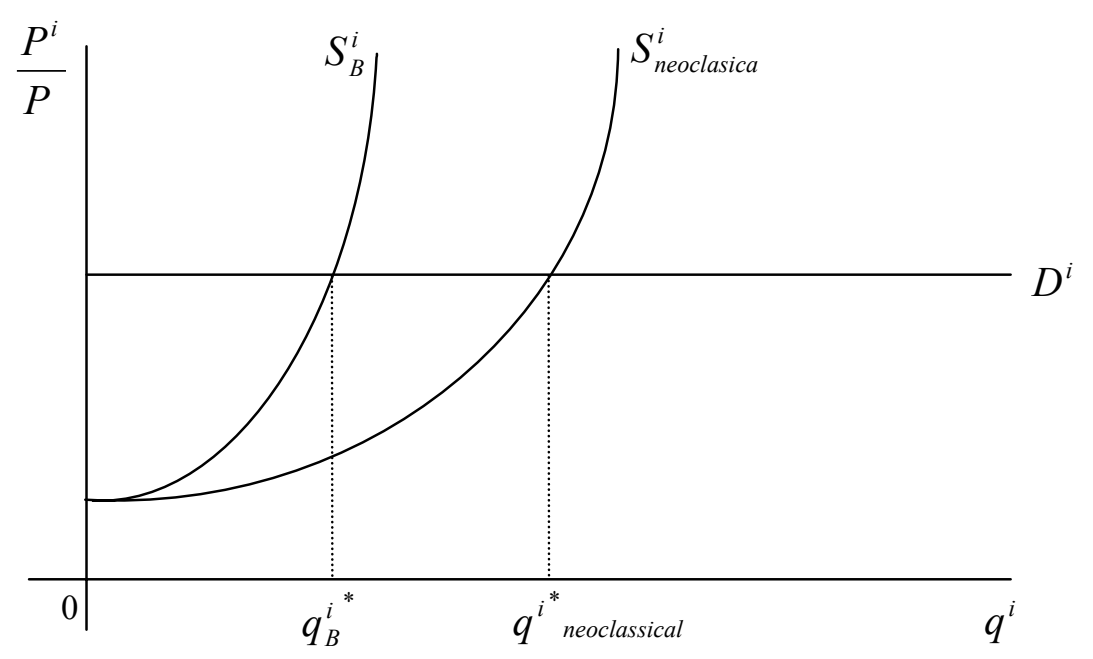

The theory of risk averse firm is for New Keynesians a critical part of their explanation of economic cycles. It is not the main concern of this paper to draw the macroeconomic consequences of the firm's risk behavior, but in case of New Keynesians it may help to understand why they are in certain aspects too extreme.

Through the theory of risk averse firm New Keynesians explain why each firm's supply curve and hence the aggregate supply curve (the amount that they are willing to produce at each level of prices) should shift markedly as the economy goes into recession (decrease in aggregate demand) and thus creating significant fluctuations in output. The decrease in demand for a firm's products decrease its prices, reduces its net worth, worsens their liquidity position. The riskiness of production has increased, the firm's willingness and ability to bear that risk has decreased due to nominal fixed repayments and increased bankruptcy costs. With greater perceived risk and lower wealth, the firm reduces its demand for inputs (with adverse effect on asset and liquidity position of other firms), which translates into a further reduction in production. In this way new Keynesians illustrate how the risk averse theory of firm can explain how the shock to the economy, whether real or monetary, can have real, large and persistent effects (more in Greenwald and Stiglitz, 1993a). In fact, the higher is the firm's aversion to risk the more it reacts on the fluctuations of prices due the business cycle and consequently further exacerbate the cycle. This is the reason why New Keynesians need a firm with strong aversion to risk.

\section{$\underline{\text { Limitations }}$}

Although their model nicely relates the financing and attitude to risk, in our opinion Greenwald and Stiglitz it is too restrictive about the firm's capital structure possibilities when saying that bond-financing is in fact the only feasible option for additional financing. The most of the financial theorists (e.g. Myers and Majluf, 1984) even within the signaling approach to capital structure understand the information asymmetries as explanation for conditions when firm may refuse to issue equity and prefer debt. However, they are far from claiming that this may cause a breakdown of the equity market and make debt the principal option for financing. As Myers (2001, p.81) points out: "there is no universal theory of the debt-equity choice, and no reason to expect one." 
In the following section we will use the example of agency theory and their incentive argument and we will show that both, debt and equity might have their advantages and disadvantages and thus the possibility of using equity should not be omitted in the models of firms.

\section{c. Agency theory}

Jensen and Meckling (1976) originated the incentive argument. They developed a theory of the firm, with specific emphasis on capital structure. The separation of owner and control give rise to agency costs. According to Jensen and Meckling, there are agency costs associated with both equity financing and debt financing. Issuing equity dilutes the manager's incentives and invites slack. To the extent the monitoring is costly the manager can enjoy greater on-thejob consumption (perquisites). They assume that the firm is partially owned by the managers. If 50 percent of the firm is owned by outsiders, manager considers each wasted dollar as costs amounting only fifty cents. A way to avoid this effect is to use debt rather than equity to finance the expansion. On the other hand highly levered firm imposes excessive agency costs associated with bankruptcy on debt holders. Also the managers have to bear a personal bankruptcy costs similar to those considered by New Keynesians. Putting the effects (agency costs) of incentive dilution from issuing a new equity and bankruptcy costs produces a tradeoff. The optimal mix of debt and equity is the situation, when the total agency costs are minimized, i.e. marginal agency costs of each category is equalized.

Grossmann and Hart (1982) developed a formal agency model with a professional manager, who has little or no stake in the firm and who controls the allocation of funds raised either through equity or debt. The professional manager decides how much to invest in a project with uncertain returns and how much to divert to private consumption (e.g. perks, status). The trade-off for the managers is between higher streams of private benefits versus higher risk of bankruptcy. The key point of the paper is that since manager has to bear bankruptcy costs, debt financing may be used as an incentive instrument as in Jensen and Meckling (1976). The choice of the debt-equity mix is influenced by this incentive effect as well as the risk that the manager will have to carry. Too much debt imply excessive risk for managers, while too little will encourage misuse of the funds.

Although agency theory has attempted to build rich theoretical foundation of capital structure and the justification of usage both, debt and equity, unfortunately it does not focus on deriving the implications on firm's attitude to risk and output behavior under uncertainty.

\section{d. Soft budget constraint concept}

The soft budget constraint concept is closely related to debt financing and it is able to provide a theoretical justification for, among other things, risk seeking behavior of firm. This kind of behavior is not explainable within the framework of the above mentioned theories of firm. This is the reason why will introduce this concept and will try to incorporate the option that firm is not facing the hard budget constraint in our model.

In practice, a number of different definitions of the soft budget constraint have been used in the literature. The most general one is provided in Kornai, Maskin, Roland (2003, p. 1097). The firm "faces a hard budget constraint as long as it does not receive support from other organizations to cover its deficit and is obliged to reduce or cease its activity if deficit persists. 
The soft budget constraint phenomenon occurs if one or more supporting organizations are ready to cover all or part of the deficit."

It was shown in extensive literature, that soft budget constraint concept is relevant also in the economic environment based on private ownership (e.g. Schaffer, 1998; Djankov, Murrel, 2002). It is not rare for firms in private ownership to get direct or indirect financial support. The support may have different forms, e.g. direct governmental bailouts, relaxed repayment terms from banks. This has been particularly evident in post-socialist transition where privatization has not ended the practice of bailouts or in East Asia before the crises in 1997, where, as Krugman (1998) argues, the government implicitly provided guarantees to private investments.

Although much of the literature (Schleifer and Vishny, 1994, Dewatripont and Maskin, 1995) gives the attention to the issue of motives of supporting organization and its inability to make a credible ex-ante promise not to support the firm (or other organization), we will focus on the consequences on the firm behavior, because for us a crucial feature of the soft budget constraint is that the support is not completely unexpected and therefore it has important consequences on manager's decisions. In fact, the soft budget constraint can be considered as a specific form of moral hazard situation resulting from the option of the firm not to fully meet its debt obligations.

An important softening instrument in the market economy is some form of credit. Let's look at how the relationship between firm and bank may look like for allowing us to say that firm faces soft budget constraint. Firstly, the relaxed repayment terms to banks may have the form of governmental guarantees (Krugman, 1998).

Secondly, state-owned banks may apply paternalistic economic policy and give firms an easy access to credit even if they are in the troublesome financial situation.

Thirdly (Dewatripont and Maskin, 1995), the banks might not require the full repayment or they might provide refinancing for the production or investment project which in the first period turns out to be unprofitable. If the firm operation would discontinue, the bank would lose its past loans. In case the bank considers the prospects of the project in the second period as sufficiently good, it may decide to refinance it, because the first-period financing is now a sunk costs and the return to the bank after refinancing the second period is greater than if the bank forces the firm to bankruptcy proceeding.

As consequence of all these forms the managers "discount" the value of debt, because they expect that they will not be forced to repay it in case the firm gets into trouble. The ability of firms to buy inputs without fully repaying them can significantly alter demand for these inputs and the level of output produced. As pointed out in Kornai, Maskin, Roland (2003) or Krugman $(1998)^{5}$ the soft budget constraint induce the firms towards higher level of investment and production levels by reducing the downside risk to the firm. The firm can anticipate the assistance from the supporting organization in case the uncertain revenues turn out to be poor. As a consequence the firms overinvest and concentrate on risky projects and the overall economy may expand too extensively from the perspective of economic efficiency.

${ }^{5}$ Although Paul Krugman in this article does not reference to soft budget constraint, his model, which attempts to explain the Asian crises in 1998, is based on financial intermediaries with implicit guarantees and thus can be considered in terms of the soft budget constraint syndrome as well. 
On the other hand the soft budget constraint resulting from the relationship with a private bank is hardly sustainable in the longer time horizon, because also the private banks face their budget constraint. If there is no permanent interference of the state institution which would provide the financial support either to the firm or to its bank, the firm will have to face the hard budget constraint in the long time horizon.

\section{e. Summary}

At this point we will summarize what the above-examined theories of firm, which work with the uncertainty, can and cannot say to our original question about the determinants of the firm's attitude to risk and its output behavior. This exercise should help us in identifying the gaps, which the model that we will develop in the remaining part of the paper will attempt to challenge. Table 1 illustrates the position of those theories of firm within our "Financing $\rightarrow$ Attitude to risk $\rightarrow$ Output behavior" framework.

In the neoclassical microeconomics the uncertainty is either assumed ${ }^{6}$ to be non-existent in the economic environment, because the agents can perfectly foresight the future events, or alternatively, the uncertainty is present, the agents are assumed to be risk-neutral and they maximize the expected value of the profits. As result, for both cases (certainty case and riskneutral producer) the optimal quantity $q_{r-n}^{*}$ is chosen so as to satisfy the equivalence of price and present value of marginal costs.

The standard theory of firm under uncertainty assumes that the firm is governed by the concave utility function, i.e. it assumes that firm is risk averse. Their models clearly demonstrate the relationship between the firm's attitude to risk and its output behavior. Their risk-averse firm produces lower level of output than the neoclassical risk-neutral firm. However, the concavity of utility function and thus the risk aversion is assumed and no satisfactory explanation for this characteristic is provided.

An important step forward is made by the New Keynesians (Greenwald and Stiglitz). They relate the firm's attitude to risk with financing issues and they show that if the firm can be financed solely through loans its behavior will be strongly risk averse and the firm will thus produce less than neoclassical risk-neutral producer. New Keynesians consider this behavior as one of the critical features of the firm behavior in general.

With the help of agency theory argument towards capital structure (and references to other approaches) we have shown the rationale for the usage of equity-financing as well. In this way we have questioned the extreme assumption of Greenwald and Stiglitz's model (1993a) about the dominant role of debt in the financing of the firm. To the knowledge of the author, the agency theory and also none of other new institutional theories models the relationship between financing and firm's attitude to risk. Therefore based on the agency theory concepts it is hardly possible to state any conditions under which the firm behave or not behave in the risk averse manner with appropriate consequences on output decisions.

The soft budget constraint literature adds another piece to the picture, which has not been covered in any of the above mentioned concepts. It demonstrates that if the firm faces soft

\footnotetext{
${ }^{6}$ In the Table 1 we denote the assumptions as " $A$ " and the results of the models as " $P$ " (propositions).
} 
budget constraint, it is induced to behave in the risk seeking manner with extensive production levels. But in the market economy this can last only in the short run time horizon.

Table 1.Summary of the theories of firm under uncertainty

\begin{tabular}{|l|c|c|c|}
\hline & Financing & Attitude to risk & Output behavior \\
\hline Neoclassical firm & $\varnothing$ & $\begin{array}{l}\text { A: certainty } \\
\text { A': risk neutral }\end{array}$ & P: $p=M C\left(q_{r-n}^{*}\right)$ \\
\hline $\begin{array}{l}\text { Standard theory of firm } \\
\text { under uncertainty }\end{array}$ & $\varnothing$ & A: risk averse & P: $q_{r-a}^{*}<q_{r-n}^{*}$ \\
\hline New Keynesians & $\begin{array}{r}\text { A: B }>0 \\
\mathrm{E}=0\end{array}$ & P: risk averse & $\mathrm{P}: q_{B}^{*}<q_{r-n}^{*}$ \\
\hline Agency theory & $\begin{array}{r}\mathrm{P}: \mathrm{B}>0 \\
\mathrm{E}>0\end{array}$ & $\varnothing$ & $\varnothing$ \\
\hline $\begin{array}{l}\text { Soft budget constraint } \\
\text { concepts }\end{array}$ & $\mathrm{A}: \mathrm{B}>0$ & P: risk seeking & $\mathrm{P}: q_{r-n}^{*}<q_{S B C}^{*}$ \\
\hline
\end{tabular}

To sum up, the most useful departure for answering our original question are the models of Greenwald and Stiglitz (New Keynesians). However, they are over-restrictive in terms of their assumptions and thus do not include all important aspects for firm behavior under uncertainty. We will attempt to enrich the Greenwald and Stiglitz's specific model for the usage of equity and the possibility of SBC and hence cover all important determinants of the attitude to risk and output behavior under uncertainty.

\section{4) Assumptions of the model}

In the remaining part of the paper we will develop our own model, which will try to address the limitations in the existing concepts we have identified above. As we have pointed the model has a number of similar features with the models of Greenwald and Stiglitz. We will therefore use their terminology and notations (when possible) for the sake of easier comparison. However, we are convinced that our model goes significantly beyond their simplified models as it does not have the ambition to provide microeconomic foundation for the macroeconomic theories.

The aim of the model described below is to provide more plastic microeconomic picture of firm behavior through abandoning Greenwald's and Stiglitz's assumption about the breakdown of equity market. In this setting their theory of firm will look like a specific case of the model presented below. Another contribution of this model should be the incorporation of the basic insights in this area from the soft budget constraint literature, which explains the risk seeking behavior of firms. The following model, therefore, attempts to unify the existing models and concepts dealing with the relationship between financing and firm's attitude to risk. The differences in relation to Greenwald and Stiglitz's models, neoclassical theory of firm and standard theory of firm under uncertainty will be discussed in more detail throughout the model.

In this section 4) we will explicitly state the core assumptions of the model. Consequently we will explain basic relations between our variables and using the financing toolbox we will graphically illustrate the impact of different parameters like net worth position, new shares, interest rate and degree of price uncertainty on the probability of bankruptcy. In the section 6) we will define the objective function of the firm and we will briefly discuss its theoretical justification. The objective function will lead us to establishing the firm's optimality 
condition. In section 7) we will compare the behavior of our firm (decision-making about the optimal output) with the alternative concepts. We will try to show, that our model is a generalization of the ones analyzed in the previous part. The following section should provide us the answer on our core question regarding the major determinants of the firm's attitude to risk and its behavior under uncertainty. Based on our model we will formulate nine propositions about the sensitivity of attitude to risk and optimal output on various parameters.

A.1 We have shown in sections 3)b and 3)c it is mostly accepted fact that the capital structure puzzle is still an unresolved issue and we still do not know how the firms decide between bonds and equity. Since we don't want to judge the relevance of different capital structure theories, we turn to the positive implications of the usage of equity vs. debt.

We will assume that a firm can partially finance its expansion of production through new equity shares. At the same time we will assume that the share between equity and bond financing is exogenously given. The reason might be the existence of optimal debt-equity mix for the given industry or because of the fact that if the firm finances the production expansion too extensively (i.e. not zero level) through new shares it will be taken as a negative signal from the investors with the negative consequences on market value.

A.2 Firms will be assumed to make decisions at discrete intervals: $t=1, \ldots, \mathrm{T}$. We will assume that future markets for products do not exist. The absence of future markets implies that firms cannot sell their output at the time of production and therefore inputs must be paid significantly before outputs are sold. There is then one period lag between the use of inputs and the availability of output. In this setting every production decision is inherently a risky investment decision and our analysis of firm behavior will focus on its willingness to undertake these risks.

A.3 The decision variable in the model will be the level of production $q_{t}^{i}$. The output decisions of firms are assumed to be made by managers who take into account not only profit maximization criteria (relevant for owners), but also the risk connected with financing the production and limited predictability of future prices. In making their economic decisions managers take into account the risk consequences, because it is usually impossible to tell whether financial bankruptcy was caused by bad luck with projects or by bad management. Thus, managers will inevitably suffer a stigma associated with bankruptcy (Eaton, Gersovitz, Stiglitz 1986). This is consistent with a view that managers maximize the probability of their survival at their positions (Hlaváček, 1999), because the risk of bankruptcy belongs among the most significant risks faced by managers.

A.4 The technology of the firm is represented by the standard real cost function ${ }^{7}$ $c=c(q)$ where $q$ is level of production, with $c^{\prime}(q)>0$ and $c^{\prime \prime}(q) \geq 0$. Firm's costs are increasing with the level of production and a firm's technology has increasing marginal costs.

A.5 The price level $P_{t}^{i}$ faced by individual firm is determined by a sectoral random variable $\tilde{u}_{t}^{i}$, and the overall price level $P$, where

$P_{t}^{i}=\tilde{u}_{t}^{i} P, E\left(\tilde{u}_{t}^{i}\right)=1$

${ }^{7}$ Throughout the whole model small letters represent variables in the real terms; the capital letters represent the nominal values of the same variables. 
The $\tilde{u}_{t}^{i}$ is the relative price of output of firm and it is exogenously given. It is i.i.d. with a distribution function $F($.$) and f($.$) . The expected relative price of output is assumed to be equal$ to unity. The relative prices are important for a firm due to the fact, that expenditures on inputs are assumed to be dependent on the overall price level $(P)$, whereas the revenues from the output produced depend on specific sector price $\left(P_{t}^{i}\right)$. The firm operates in competitive market and it is a price-taker.

A.6 It is assumed that if the nominal net worth position of firm is negative $\left(A_{t}<0\right)$ the firm goes bankrupt and that all the revenues from the sale of $q_{t-1}^{i}$ are distributed to debt-holders.

A.7 In the section 3)d we have defined the term soft budget constraint and we have pointed out on three forms of the relationship between the firm and the bank consistent with soft budget constraint. All these forms result in some form of not full or not on-time repayment of the credit or at least they create the expectation of managers that the firm will have the freedom not to fully repay.

In our model we will associate the degree to which budget constraint related to debt is soft with the parameter $I_{t}^{i}$. The softness of the budget constraint ${ }^{8}$ is exogenous to our model and the value of the parameter $I_{t}^{i}$ will range between zero and unity, $I_{t}^{i} \in\langle 0 ; 1\rangle$. The parameter $I_{t}^{i}$ can be also understood as a "discount" factor, which managers associate to debt due to soft budget constraint. $I_{t}^{i} B_{t}^{i}$ represents the value of debt $B_{t}^{i}$, which the firm expects that it will be forced to repay.

The decrease in $I_{t}^{i}$ will simulate the increase in the degree of softness of the budget constraint. Under standard market condition $I_{t}^{i}$ is equal to one and the more there is moral hazard in firm's decision-making due to soft budget constraint the closer to zero the parameter $I_{t}^{i}$ will be.

As the net worth position is dependent on the level of debt, which the firm has to repay (see the equation (1) below), the lower $I_{t}^{i}$ may artificially keep the net worth positive (i.e. the company would not go to bankruptcy). The A.5 therefore still holds, even though under standard market conditions $\left(I_{t}^{i}=1\right)$ the firm would be bankrupt. However, in compliance with what we have explained in section 3)d, we assume that $I_{t}^{i}$ being significantly below one may be possible only in the medium term, but not sustainable in the long run. In the long run horizon the $I_{t}^{i}$ move towards 1 , i.e. standard market conditions, when debts has to be fully repaid by a firm or the firm has to go to bankruptcy.

A.8 For the sake of simplicity we assume, that the price level does not change between the periods, $P_{t}=P_{t+1}$. We will denote the price as independent on time, $P$. Therefore, in this model, the only source of risk is the relative price of output, because the development of firm

${ }^{8}$ It is assumed that the degree of softness of the budget constraint is rather firm specific (e.g. the firm is "too big to fail" or it has strategic importance for state or financing institution) rather than the feature of the given economic environment. Therefore the notation is $I_{t}^{i}$ and not $I_{t}$. 
specific output price $P_{t}^{i}$ may be different to the development of the input prices $P$ related to price level.

A.9 We assume that output $q_{t-1}^{i}$ has zero supply elasticity and must be all sold at the beginning of the following period $t$, when it becomes available.

\section{5) Probability of bankruptcy}

The nominal net worth position $A_{t}^{i}$, which determines the solvency of a firm, results from the production and financing decision made in period t-1. A firm inherits the nominal level of debt $B_{t-1}^{i}$ and nominal level of new shares ${ }^{9} S_{t-1}^{i}$ in order to pay for the inputs that were required for producing $q_{t-1}^{i}$. Associated with the debt is a contractual interest rate $r_{t-1}^{i}$ and the degree to which the budget constraint is soft $I_{t}^{i}$. The contractual repayment owed to debtholders by firm " $\mathrm{i}$ " is $\left(1+r_{t-1}^{i}\right) B_{t-1}^{i}$. The nominal net worth position is also determined by the price $P_{t}^{i}$ at which the firm sells the inherited output $q_{t-1}^{i}$.

$$
A_{t}^{i}=P_{t}^{i} q_{t-1}^{i}-\left(1+r_{t-1}^{i}\right) B_{t-1}^{i} I_{t}^{i}+S_{t-1}
$$

The difference between net worth $A_{t-1}^{i}$ and new shares $S_{t-1}^{i}$ is straightforward. Net worth is defined as all assets minus all liabilities. Putting differently, nominal net worth position $A_{t-1}^{i}$ represents cumulative nominal book value of old shares (before the period t-1) plus cumulative nominal value of old profits (before the period t-1). On the other hand new shares $S_{t-1}^{i}$ represent the nominal book value of the new shares issued at the period $\mathrm{t}-1$ as another source of financing of the production.

A firm borrows $B_{t}^{i}$ and issues equity $S_{t}^{i}$ in order to supplement own resources (net worth) when paying the production costs. The level of required additional financing thus depends on the difference between the level of costs and net worth position. The firm has two options of financing this difference: through debt or through issuing a new equity. Since cost function is defined in real terms we can write

$B_{t}^{i}+S_{t}^{i}=P c\left(q_{t}^{i}\right)-A_{t}^{i}$

\section{$\underline{\text { Bankruptcy conditions }}$}

In the second stage, after the prices in period $\mathrm{t}+1$ are revealed, the firm goes bankrupt if it is obliged repay more than their income allows it to do. Using assumption A.6 and equation (1), we get:

${ }^{9}$ It is important to notice, that the new shares does not relate to the market value of those shares, but to the book value of the shares. This is because we focus on shares as an alternative source of financing from the perspective of the firm and not on its profitability related to share-holders. 


$$
P_{t+1}^{i} q_{t}^{i}+S_{t}^{i}<\left(1+r_{t}^{i}\right) B_{t}^{i} I_{t}^{i}
$$

Or alternatively we can express this condition by using A.5 and equation (2)

$$
P \tilde{u}_{t+1}^{i} q_{t}+S_{t}^{i}<\left(1+r_{t}^{i}\right) I_{t}^{i}\left(P c\left(q_{t}^{i}\right)-A_{t}^{i}-S_{t}^{i}\right)
$$

and thus using the assumption A.8 we get

$$
\frac{P_{t+1}^{i}}{P}=\tilde{u}_{t+1}^{i}<\frac{\left(1+r_{t}^{i}\right) I_{t}^{i}\left(c\left(q_{t}^{i}\right)-a_{t}^{i}-s_{t}^{i}\right)-s_{t}^{i}}{q_{t}^{i}}=\bar{u}_{t+1}^{i}
$$

where $\bar{u}_{t+1}^{i}$ is level of relative prices in period $\mathrm{t}+1$ at which the firm is just solvent, $a_{t}^{i}=\frac{A_{t}^{i}}{P}$ is real equity and $s_{t}^{i}=\frac{S_{t}^{i}}{P}$ is real new shares. We have thus extracted the external sectoral and overall price developments on one side $\left(P_{t}^{i}, P\right)$ and the internal structure of firm on the other side, which shows how big changes of relative prices the company is able to absorb without going to bankruptcy. The company is more resistant to bankruptcy risk (i.e. decrease of $\bar{u}_{t+1}^{i}$ ) with increase in real net worth position, real new shares issued in period $\mathrm{t}$, decrease in $I_{t}^{i}$ (the budget constraint is softer) and decrease in nominal contractual interest rate. These relationships are in compliance with the basic economic intuition.

\section{$\underline{\text { Probability of bankruptcy and its determinants }}$}

A.10 We assume that firms can borrow as much as they wish as long as the lender gets the expected return amounting $1+r_{t}^{f}$, where $r_{t}^{f}$ is the risk-free interest rate. The lender takes into account not only the regular repayments amounting $1+r_{t}^{i}$ in the situations when a firm is solvent if $\tilde{u}_{t+1}^{i} \geq \bar{u}_{t+1}^{i}$, but also real return $1+r_{t}^{i, B T}$ when a firm is insolvent and when a firm cannot meet all its debt obligations, i.e. if $\widetilde{u}_{t+1}^{i}<\bar{u}_{t+1}^{i}$.

Therefore the contractual interest rate is determined according to the following equation:

$1+r_{t}^{f}=\left(1+r_{t}^{i}\right)\left(1-F\left(\bar{u}_{t+1}^{i}\right)\right)+F\left(\bar{u}_{t+1}^{i}\right)\left(1+r_{t}^{i, B T}\right)$

where $\mathrm{F}($.$) is the probability distribution of relative prices and where F\left(\bar{u}_{t+1}^{i}\right)$ is defined as the probability of bankruptcy.

The equation (6) says, that the individual firm pays via its contractual interest rate not only the opportunity costs (risk free interest rate), but as well, it pays to the lender for the risk, that the firm will go to bankruptcy a will thus be unable to fully repay the debt. From the very definition of bankruptcy the return of debt is higher if the firm is solvent $\left(1+r_{t}^{i}\right)$ than the real return in case it is bankrupt $\left(1+r_{t}^{i, B T}\right)$. As a consequence, the contractual interest rate is higher than and increasing with the risk-free interest rate, increasing with the probability of bankruptcy and decreasing with amount the lender can get from the firm during the bankruptcy procedure $r_{t}^{i, B T}$.

The probability of bankruptcy $F\left(\bar{u}_{t+1}^{i}\right)=F\left(\bar{u}_{t+1}^{i}\left(q_{t}^{i}, a_{t}^{i}, s_{t}^{i}, I_{t}^{i}, r_{t}^{f}\right)\right)$ is directly positively dependent on $\bar{u}_{t+1}^{i}$ (defined in equation (5)). It is increasing with the increase of interest rate 
$\left(r_{t}^{i}\right)$, "hardness" of budget constraint $\left(I_{t}^{i}\right)$ and decreasing with initial real net worth position $\left(a_{t}^{i}\right)$, amount of new shares $\left(s_{t}^{i}\right)$. The shape of the distribution function $\mathrm{F}($.$) expresses the$ degree of uncertainty concerning future prices.

We can graphically illustrate the logic of this section and the interrelatedness of various parameters with the probability of bankruptcy. On horizontal axis we put the uncertain relative prices of inputs and output $\left(\tilde{u}_{t+1}^{i}\right)$; and on the vertical axis we plot the firm's gross margin (black line), return of owners (blue line) and return of bondholders (red line).

\section{Chart 2. Impact of the major parameters on the probability of bankruptcy}

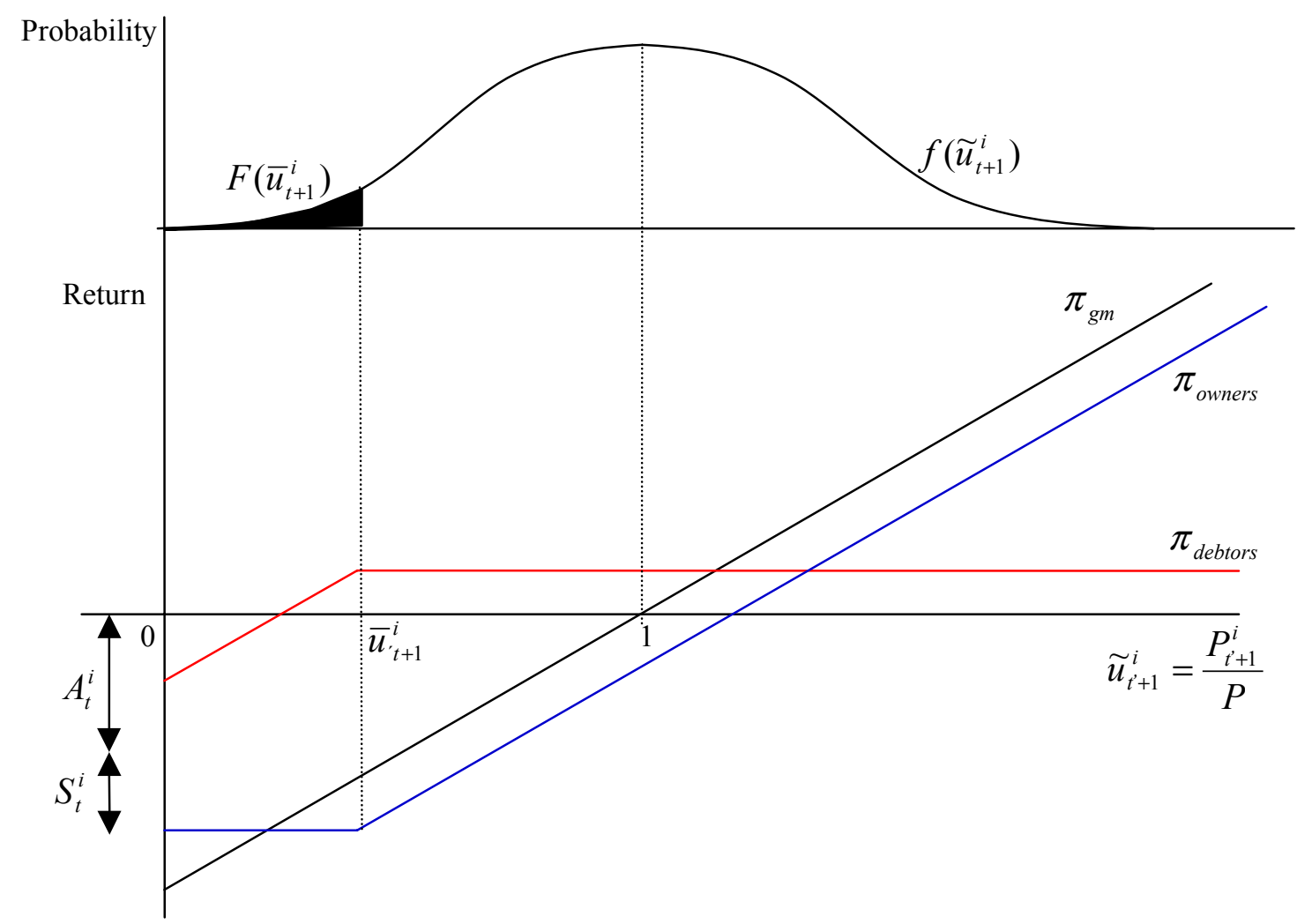

Firm's gross margin is defined as the difference between revenues and costs of production $\left(\pi_{g m}=P_{t+1}^{i} q_{t}^{i}-P c\left(q_{t}^{i}\right)\right)$. The $\pi_{g m}$ curve is linear, because we keep the production level constant (i.e. the costs) and we plot the relationship only with uncertain relative prices $\tilde{u}$.

The return of owners is defined as firm's gross margin minus interest rates ( $\pi_{\text {owners }}=P_{t+1}^{i} q_{t}^{i}-P c\left(q_{t}^{i}\right)-r_{t}^{i} B_{t}^{i}$ ), if the actual level of relative prices is higher or equal than the level of relative prices when a firm is just solvent $\left(\tilde{u}_{t+1}^{i} \geq \bar{u}_{t+1}^{i}\right)$; and as the loss amounting the total liability of owners (i.e. nominal net worth position plus new shares, $\left.\pi_{\text {owners }}=-A_{t}^{i}-S_{t}^{i}\right)$, if the actual relative prices are lower than the level when a firm is just solvent $\left(\tilde{u}_{t+1}^{i}<\bar{u}_{t+1}^{i}\right)$. 
The return of bondholders is equal either to the contractual interest rate $\left(\pi_{\text {debtors }}=r_{t}^{i} B_{t}^{i}\right)$ if firm is solvent or to the income, which is distributed among debtors when a firm is insolvent. If we sum the return of owners and debtors we get exactly the amount of gross margin for every level of relative prices.

In the upper part of the Chart 2 we have plotted the probability density $\mathrm{f}($.$) of relative prices.$ The area under the density function up to the solvency relative prices $\bar{u}_{t+1}^{i}$ measures the probability of bankruptcy $F\left(\bar{u}_{t+1}^{i}\right)$.

Let's graphically analyze the impact of major parameters of our model on the probability of bankruptcy $F\left(\bar{u}_{t+1}^{i}\right)$ for a given $q_{t}^{i}$.

Firstly, the increase in the contractual interest rate shifts the curve representing the return of debtors $\pi_{\text {debtors }}$ up (red dashed line), because $r_{t}^{i} B_{t}^{i}$ increases. At the same time the return to owners $\pi_{\text {owners }}$ shifts to the right due to the increased repayments to debt-holders. The gross margin curve remains the same. As a result, this change increases the expected return of debtors at the expense of owners and also, it increases the probability of bankruptcy, because $\bar{u}_{t+1}^{i}$ increases (see Chart 3).

Chart 3. Impact of increase in the contractual interest rate on the probability of bankruptcy

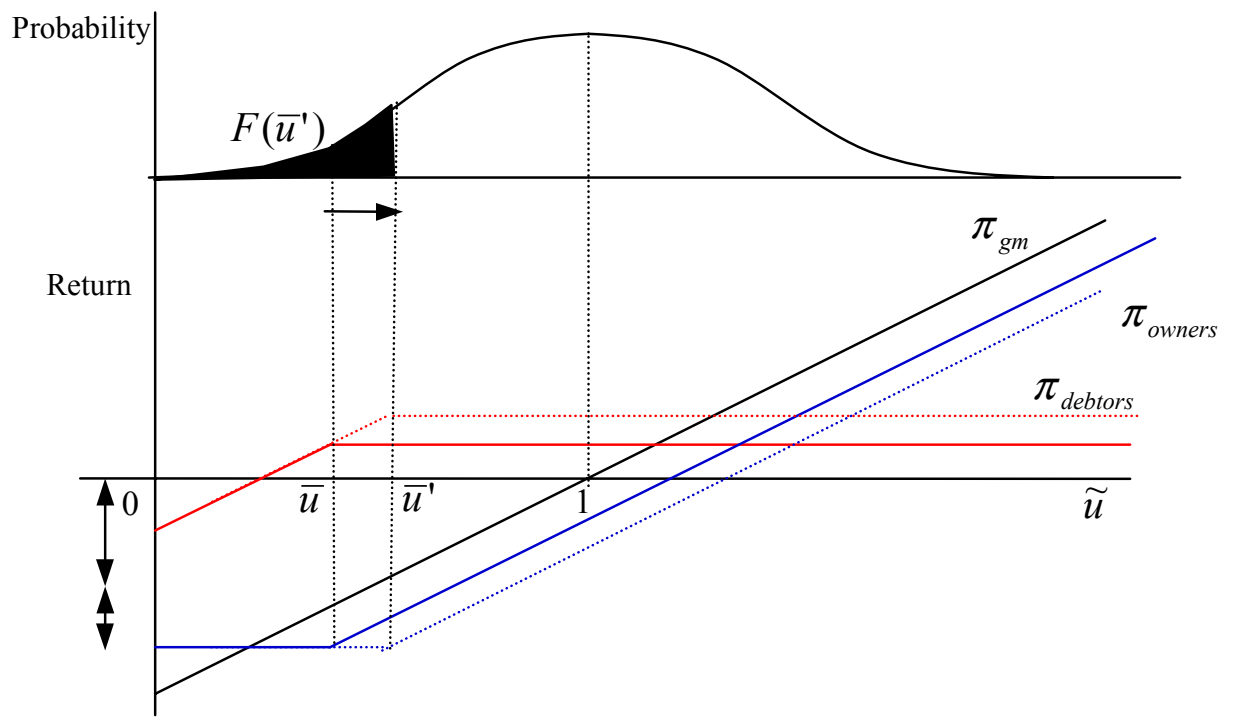

Secondly, the net worth position of firm has a direct impact on the shape of the return curve of owners as it increases the liability of owners and thus decreases the solvency level of relative prices $\bar{u}_{t+1}^{i}$. It might be the case that the net worth position is so high that even in the worst case, when relative prices are equal to zero, a firm does not need to go bankrupt. In our scheme the amount of $A_{t}^{i}$ would be bigger than the distance between zero return and the intersection of gross margin curve with the vertical axis. 
Thirdly, the increase of new shares $S_{t}^{i}$ has two effects (see Chart 4). It increases owner's total liabilities in the same manner as $A_{t}^{i}$ does. Moreover, financing through new shares is an alternative to bond financing. As the financing through the new shares increases bond financing decreases. Consequently, the repayments to debtors decrease for all levels of relative prices, $\pi_{\text {debtors }}$ shifts down, $\pi_{\text {owners }}$ shifts to the left. Both effects lead to the decrease of probability of bankruptcy.

\section{Chart 4. Impact of increase in the new shares on the probability of bankruptcy}

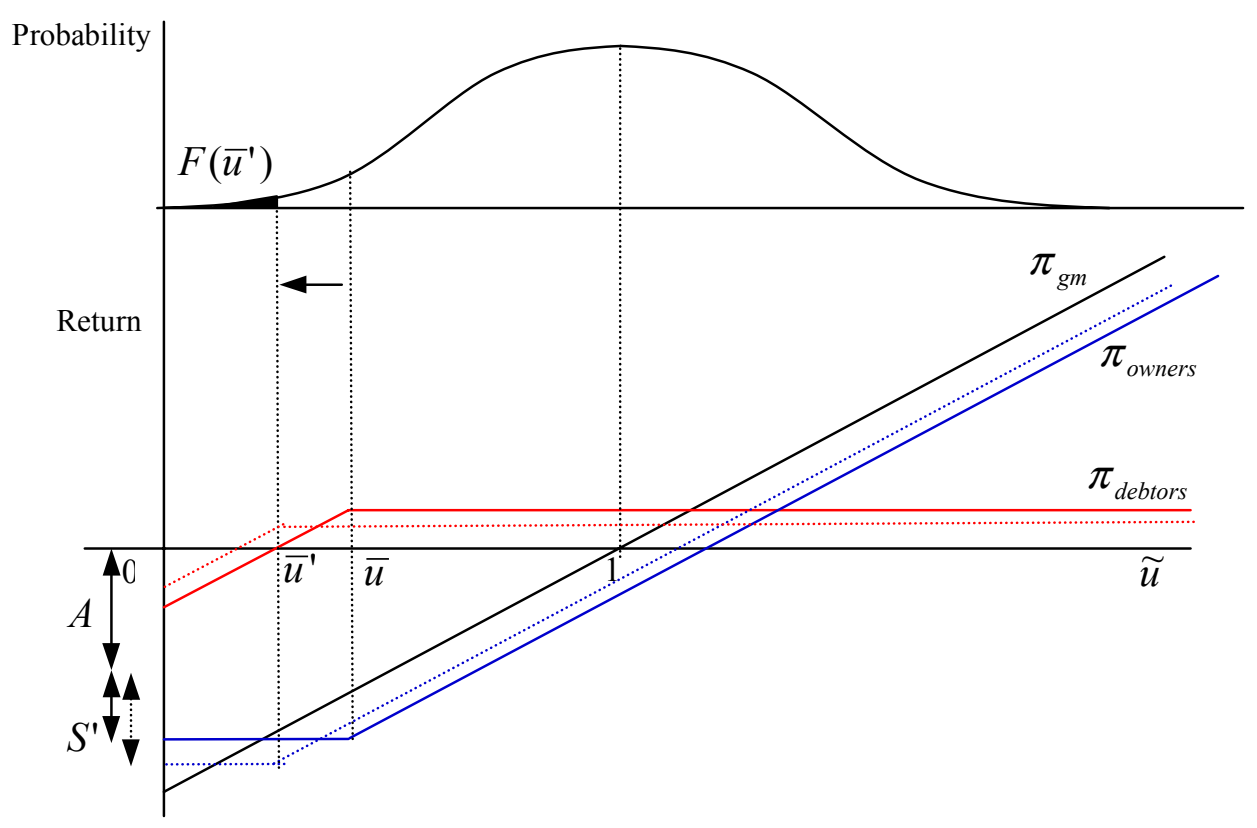

Forth, an important factor is also the shape of the distribution of future prices, which represents the extent of uncertainty. For a given $\bar{u}_{t+1}^{i}$ the shape of density function directly influences the size of the area illustrating the probability of bankruptcy $F\left(\bar{u}_{t+1}^{i}\right)$. Let us define increase in price uncertainty as a "stretching" of the probability distribution around a constant mean (Sandmo, 1971). In the Chart 5 the probability function $\mathrm{g}($.$) corresponds to the more$ risky distribution of prices (i.e. with higher variance). Consequently, we can see that the probability of bankruptcy is increasing with the price uncertainty, if the solvency level of relative prices is lower than unity (i.e. expected level of relative prices) and $F(\bar{u})<G(\bar{u})$. In other words, if it is more probable that the firm survives than that it will go bankrupt than price uncertainty is bad thing from the perspective of its survival.

If the situation is inverse, i.e. if $\bar{u}^{\prime}$ is very high and the firm has poor chance for survival, the increase in price uncertainty may help the firm out of the trouble via extremely high prices. The probability of bankruptcy thus decreases, $F\left(\bar{u}^{\prime}\right)>G\left(\bar{u}^{\prime}\right)$. We will analyze this paradox in more detail in section 8 )e, at this point stating these effects on probability of bankruptcy should be sufficient. 


\section{Chart 5. Impact of increase in the price uncertainty on the probability of bankruptcy}

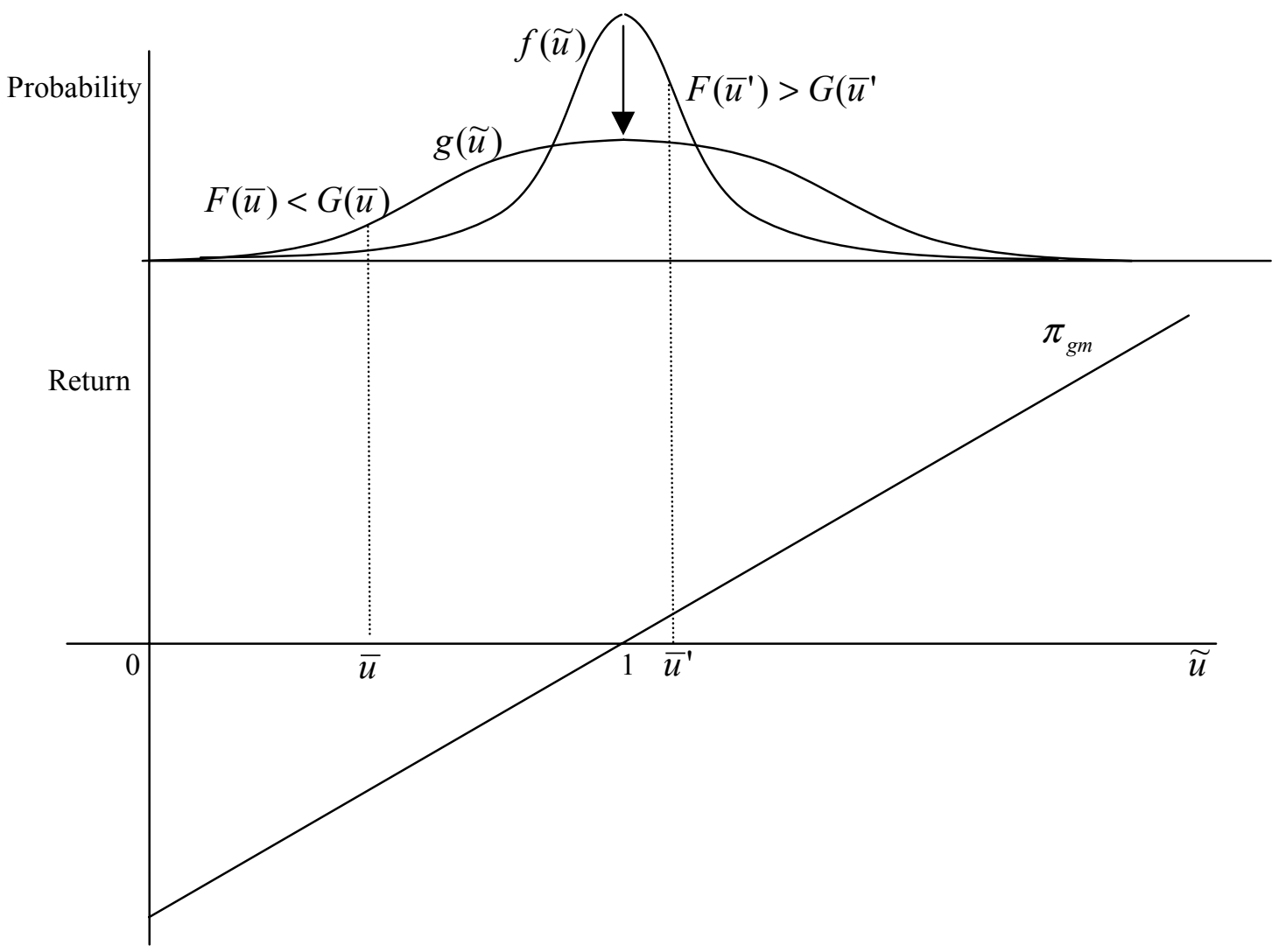

\section{6) Firm's objective function}

The managers select the output level so as to maximize expected profit (expected revenues minus "repayments" to capital providers for financing the costs of production) minus their personal costs of bankruptcy $k_{t}^{i}$ (i.e. costs of bankruptcy multiplied by probability of bankruptcy). The repayments to capital providers include not only repayments to lenders (i.e. banks), but also notional "repayment" to the investors of the new shares in the amount of present value of the new shares. The new shares cannot be understood as a part of firm's profit, because managers have to minimize the additional financing through new shares $S_{t}^{i}$ similarly as through the financing through loans. Similar logic thus should be applied.

The objective function with these features can be expressed in the following way:

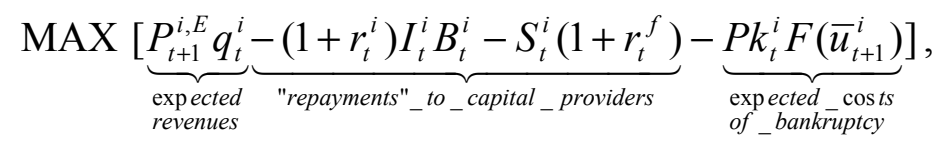

The costs of bankruptcy represent the negative attitude of various stakeholders (especially managers and employees) towards bankruptcy. The standard theory of firm under uncertainty (Sandmo, 1971, Gravelle and Rees, 1992) captures the hypothesis, that firm acts to avoid bankruptcy, by simple assumption, that firm is owner-managed and that this owner maximizes expected utility of profits with utility function characterized by decreasing marginal utility of profit. In Greenwald and Stiglitz 1987, 1990 the same idea is embodied in decreasing absolute 
risk aversion of owner-manager. In this model we focus on firm with divided ownership and control and therefore consider a manager as a primer decision-maker in a firm. We assume that managers take into account the personal costs associated with bankruptcy (A.3, similarly as Greenwald and Stiglitz 1993a). The managers are subject to an agency agreement that rewards them with a share of profits, but have to bear a large penalty in the event of bankruptcy (stigma of unsuccessful manager).

A.12 We assume that the bankruptcy costs are increasing with the size of firm, which is compliance with economic intuition about the reality. The bigger the firm is, the more managers (and employees) are involved, whose loss of position and income would increase with the firm's size. This justification also points out on the consequences of the principalagent issues, because the interests of owners and managers are not in full compliance as the managers include their personal costs into the objective function of a firm, which should be irrelevant from the owner's perspective.

We will use quantity as the proxy variable for the firm's size as it is the only scale variable in the model and thus the real bankruptcy costs are defined as follows: ${ }^{10}$

$$
k_{t}^{i}=k q_{t}^{i}
$$

The real bankruptcy costs are linear relationship to the level of production of a firm, where $k$ is the sensitivity of managers to bankruptcy.

Using equations (8), (2) and assumptions A.5 we can rewrite the same objective function as

$$
\operatorname{MAX}\left[P_{t+1}^{i, E} q_{t}^{i}-\left(1+r_{t}^{i}\right) I_{t}^{i}\left(P c\left(q_{t}^{i}\right)-A_{t}^{i}-S_{t}^{i}\right)-S_{t}^{i}\left(1+r_{t}^{f}\right)-P k q_{t}^{i} F\left(\bar{u}_{t+1}^{i}\right)\right]
$$

We can write the objective function in equation (9) in real terms as follows:

$$
\operatorname{MAX}\left[\frac{P_{t^{\prime}+1}^{i, E}}{P} q_{t}^{i}-\left(1+r_{t}^{i}\right) I_{t}^{i}\left(c\left(q_{t}^{i}\right)-a_{t}^{i}-s_{t}^{i}\right)-s_{t}^{i}\left(1+r_{t}^{f}\right)-k q_{t}^{i} F\left(\bar{u}_{t+1}^{i}\right)\right]
$$

As only real variables matter in the decision-making about the output, there is no space for price illusion. For expository purpose we keep $\frac{P_{t+1}^{i, E}}{P}$ in the equations even though with a strict application of our assumptions A.5 and A.8 we could consider this variable being equal to 1 . However, this step is not necessary for seeing the central conclusions of this model and keeping this item in the equation does not impose so much restriction on the type of expectation formation as A.5 does.

\section{First order conditions}

If above stated assumptions are fulfilled then the firm behavior (real output) is determined by real interest rates, softness of the budget constraint, technology, firm's ability to raise new shares, real equity, real bankruptcy costs and relative price uncertainty.

After simple derivation of equation (10) according to q we get the first order equilibrium condition

${ }^{10}$ Besides this reasoning, the dependence of bankruptcy costs on size of a firm is important from the technical point of view of this model as with bankruptcy costs having fixed, they could be easily mitigated through expansion of production. 
$\frac{P_{t+1}^{i, E}}{P}-\left(1+r_{t}^{i}\right) I_{t}^{i}\left(c^{\prime}\left(q_{t}^{i^{*}}\right)-\frac{\partial s_{t}^{i}}{\partial q_{t}^{i}}\right)-\frac{\partial s_{t}^{i}}{\partial q_{t}^{i}}\left(1+r_{t}^{f}\right)+\eta_{t}^{i}=0$

where $\eta_{t}^{i}$ is marginal bankruptcy costs of firm "ip" in period t, i.e.

$\eta_{t}^{i}=k F\left(\bar{u}_{t+1}^{i}\right)+k q_{t}^{i} f\left(\bar{u}_{t+1}^{i}\right) \frac{\partial \bar{u}_{t+1}^{i}}{\partial q_{t}^{i}}$

and thus $\eta_{t}^{i}=\eta_{t}^{i}\left(k, q_{t}^{i}, a_{t}^{i}, s_{t}^{i}, I_{t}, r_{t}^{i}\right)$ and can be understood as risk premium for additional production.

$\underline{\text { Exogenous and endogenous variables }}$

Before we turn our attention to the explanation firm's behavior under uncertainty resulting from our model, let's recapitulate the variables and break them up on those which are exogenous and those which are endogenous. The exogenous parameters are the following:

- the density of the probability distribution of relative prices $\mathrm{f}($.$) ,$

- the net worth position $A_{t}^{i}$,

- the risk-free interest rate $r_{t}^{f}$,

- the division of the total amount of the necessary financial resources between debt $B_{t}^{i}$ and new shares $S_{t}^{i}$ (capital structure),

- firm's ability to raise new shares for financing production expansion $\frac{\partial s_{t}^{i}}{\partial q_{t}^{i}}$,

- the softness of the budget constraint $I_{t}^{i}$,

- the sensitivity of managers towards bankruptcy $k$,

- the relative prices $\frac{P_{t}^{i}}{P}=\tilde{u}_{t}^{i}$

- the expected sector price ${ }^{11} P_{t+1}^{i, E}$.

The model has the following endogenous variables:

- the total amount of necessary financial resources $B_{t}^{i}+S_{t}^{i}$

- the level of relative prices, when the firm is just solvent $\bar{u}_{t}^{i}$,

- the contractual interest rate $r_{t}^{i}$,

- the probability of bankruptcy $F\left(\bar{u}_{t}^{i}\right)$,

- the risk premium associated with bankruptcy/marginal bankruptcy costs $\eta_{t}^{i}$,

- the optimal level of output $q_{t}^{i^{*}}$.

${ }^{11}$ This variable can be eliminated once we would apply A.5. 


\section{7) Firm's supply under uncertainty}

The equilibrium condition (13) below is the central outcome of our model. At first (in the sections a - c) we will try to show that the behavior of our firm is a generalization of the existing concepts of firm under uncertainty and that it can account for the major conclusions of the so-far-disjoint concepts presented in sections 3)a - 3)d. Consequently (section 8)), we will make a sensitivity analysis of the optimal output on the major parameters. This exercise will allow us to devise nine propositions about the determinants of the firm's attitude to risk and the impact on firm behavior. In this way we will answer our core question, which we have posed at the introduction.

We can rewrite the equilibrium (11) condition so that:

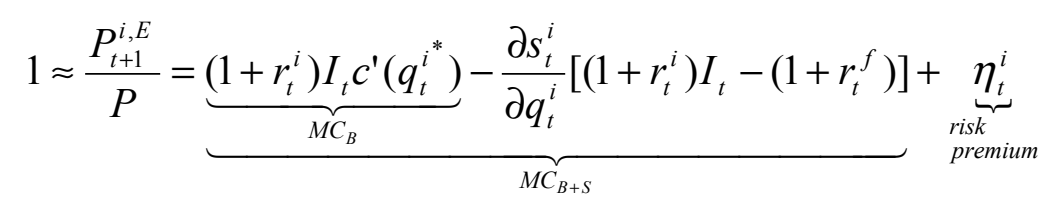

\section{a. Neoclassical firm behavior}

The first question which is naturally raised by the introduction of price uncertainty and financing issues is this: how does the optimal output compare with the well-known neoclassical solution? The traditional neoclassical analysis says that a firm maximizes its profit and therefore a firm produces up to the point when the market price is equal to the present value of the marginal costs. This simple profit maximization objective do not take into account the changes of behavior due to the risk of production. The profit maximization assumption implies behavior in the risk neutral manner.

We can easily see that standard neoclassical firm behavior is a special case of our model. It is the situation when:

- firm faces hard budget constraint $\left(I_{t}^{i}=1\right)$ and

- the costs of production expansion can be fully financed by the new shares $\left(c^{\prime}\left(q_{t}^{i}\right)=\frac{\partial s_{t}^{i}}{\partial q_{t}^{i}}\right)$

As the event of bankruptcy is possible only when the company is at least partially financed by debt, the risk premium ( $\eta_{i}^{t}$ marginal costs of bankruptcy) is equal to zero. Thus we can write:

$\frac{P_{t+1}^{i, E}}{P}=\left(1+r_{t}^{i}\right) c^{\prime}\left(q_{t}^{i^{*}}\right)-c^{\prime}\left(q_{t}^{i^{*}}\right)\left(r_{t}^{i}-r_{t}^{f}\right)+\eta_{t}^{i}=\left(1+r_{t}^{f}\right) c^{\prime}\left(q_{t}^{i^{*}}\right)$

This outcome is the traditional neoclassical result taking into account the fact that the costs are paid one period before the output is received and opportunity costs (risk free real interest rate) thus must be included. 


\section{b. Firm behavior with hard budget constraint and bankruptcy risk}

If firm faces hard budget constraint $\left(I_{t}=1\right)$, the managers choose the level output according to the following equation:

$$
\frac{P_{t+1}^{i, E}}{P}=\underbrace{\underbrace{\left(1+r_{t}^{i}\right) c^{\prime}\left(q_{t}^{i^{*}}\right)}_{M C_{B}}-\frac{\partial s_{t}^{i}}{\partial q_{t}^{i}}\left(r_{t}^{i}-r_{t}^{f}\right)}_{M C_{B+S}}+\underbrace{\eta_{t}^{i}}_{\substack{\text { risk } \\ \text { premium }}}
$$

The first item on the right hand side represents the marginal costs of production in the situation when the firm is solely bond-financed $\left(M C_{B}\right)$. The second item measures, how the marginal costs change in case the production is partially financed by the issuance of equity. The contractual interest rate is by definition (equation 6) higher than the risk free interest rate, because it includes the possibility, that a firm will go bankrupt, whereas risk free interest does not. The second item is always negative and contributes to decrease of "marginal costs of production and financing" (the first two items together, $M C_{B+S}$ ).

It is interesting to notice, that to the extent a firm can raise new shares ${ }^{12}$ on the capital market $\left(\frac{\partial s_{t}^{i}}{\partial q_{t}^{i}} \in\left\langle 0 ; c^{\prime}\left(q_{t}^{i}\right)\right\rangle\right)$ in order to finance its additional production $c^{\prime}\left(q_{t}^{i}\right)$, the marginal costs of production and financing move towards the level of marginal costs related to traditional risk neutral firm as we have shown in the previous section.

The third item $\eta_{i}^{t}$ is another departure from the traditional risk-neutral neoclassical equilibrium. The bond-financed (or co-financed) firm has to face the risk bankruptcy. As a consequence the marginal bankruptcy costs $\eta_{i}^{t}$ (risk premium) are positive. As the marginal costs of production are increasing, the impact of bankruptcy risk is to restrict optimal output level, because the marginal costs of production are increasing with quantity. The risk premium, which lowers the output, increases with the increase in the real interest rates, with the extent, to which the production expansion is bond-financed, with the increase of sensitivity of managers to bankruptcy and with decrease in the net worth position (more in section 8)).

In this way these risks drive wedge between expected prices and marginal costs in traditional sense. The Chart 6 illustrates the situation graphically.

${ }^{12}$ As pointed out in the section 4) we assume (A.1) that due to asymmetric information there is certain level above which issuing new equity shares means negative signal for potential equity investors leading to the decrease of the market of value of a given firm. A firm is thus constrained in its decision-making about how much of the additional production can be financed by equity, $\frac{\partial s_{t}^{i}}{\partial q_{t}^{i}} \leq c^{\prime}\left(q_{t}^{i}\right)$. At the same time we realistically assume that a firm does not buy-out its shares from the market during its expansion and issue the new shares during the period of slump in production. Therefore $\frac{\partial s_{t}^{i}}{\partial q_{t}^{i}} \geq 0$. 


\section{Chart 6. Risk behavior with hard budget constraint (i.e. $I=1$ )}

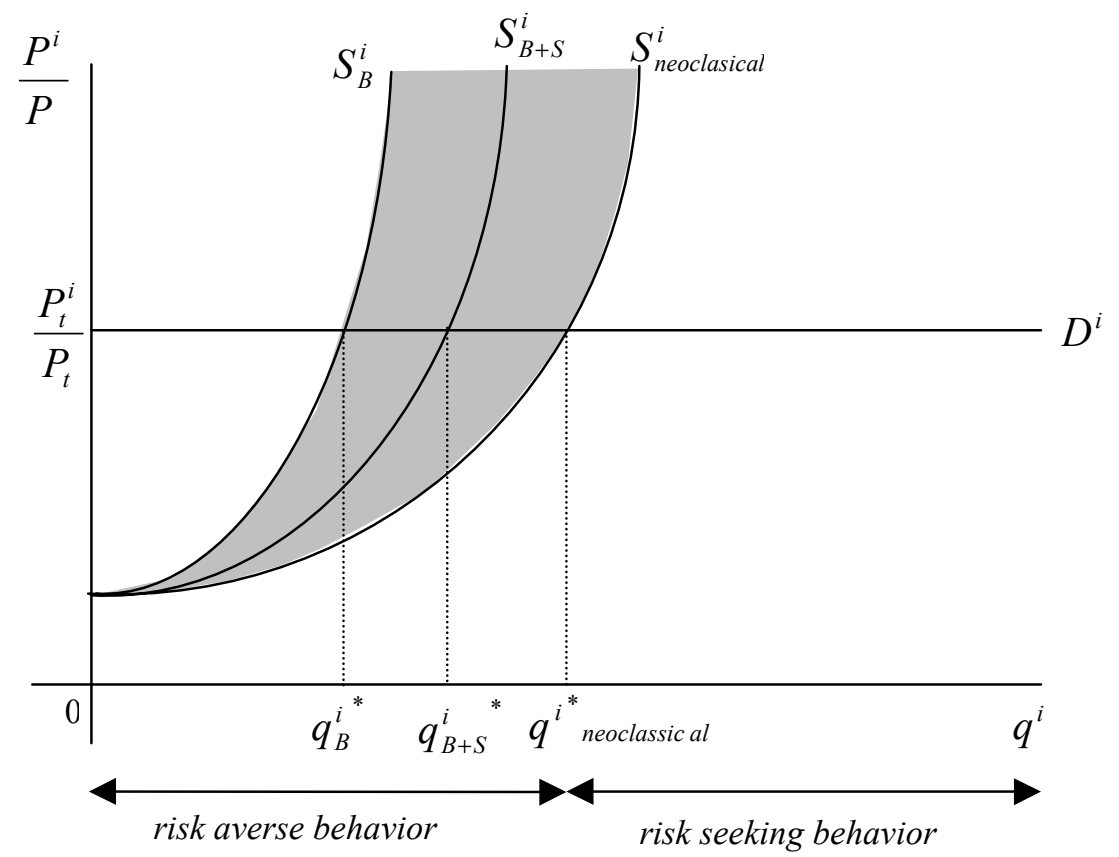

Let's compare these outcomes with the models developed by Greenwald and Stiglitz. These authors consider the situation when a firm is solely bond-financed, because the equity market is broken down due to asymmetric information. As consequence the second item in the equation is equal to zero as a firm cannot raise new shares and "marginal costs of production and financing" are thus higher than with co-financing. At the same time the risk premium with solely bond-financing is the maximum of the risk premiums associated with co-financing (bonds and new shares). These both effects lead to a firm with highest possible risk aversion and lowest optimal level of output from the perspective of our model other things being equal (see supply curve $S_{B}^{i}$ in Chart 6) ${ }^{13}$. In our model new shares work as buffer to absorb risks. The more the firm has access to equity financing the less risk averse it will be and the supply curve will be shifting to the right towards supply curve associated with risk neutral firm. In the Chart 6 this logic is captured by our supply curve $S_{B+S}^{i}$, which is located in the shadowy space between Greenwald and Stiglitz's firm and neoclassical firm.

\section{c. Firm behavior with soft budget constraint}

In this subsection we will analyze the behavior of our modeled firm in the situation, when it faces a soft budget constraint. In other words, we will look at the consequences, when the

${ }^{13}$ Using the notation of our model, the optimality condition in Greenwald and Stiglitz (1993a) would be the following: $1=\left(1+r_{t}^{i}\right) c^{\prime}\left(q_{t}^{i^{*}}\right)+\operatorname{MAX}\left[\eta_{t}^{i}(S, B)\right]$. 
probability, that a firm will have to fully repay its debt obligations, is significantly lower than unity $\left(I_{t}^{i}<1\right)$.

In general, the optimum condition of our firm is the equation (13)

$$
\frac{P_{t+1}^{i, E}}{P}=\left(1+r_{t}^{i}\right) I_{t}^{i} c^{\prime}\left(q_{t}^{i^{*}}\right)-\frac{\partial s_{t}^{i}}{\partial q_{t}^{i}}\left[\left(1+r_{t}^{i}\right) I_{t}^{i}-\left(1+r_{t}^{f}\right)\right]+\eta_{t}^{i}
$$

The second item on the right hand side of the equation will be negative or equal to zero until the following condition holds: $\left(1+r_{t}^{i}\right) I_{t}^{i} \geq\left(1+r_{t}^{f}\right)$. For the situations near hard budget constraint the possibility to raise new equity shares will decrease "marginal costs of production and financing" as was described in previous section. However, if $I_{t}^{i}<\frac{1+r_{t}^{f}}{1+r_{t}^{i}}$, it is more desirable for the managers to finance the production through loans. While we assume that a firm is not constrained in bond financing (in contrary to new shares), the production will be solely financed by debt and thus $\frac{\partial s_{t}^{i}}{\partial q_{t}^{i}}=0$. Therefore the second item will be equal to zero.

The third item on the right hand side, the bankruptcy risk premium is lower the softer is the budget constraint (i.e. the lower is $I_{t}^{i}$ ). More intuitively, the managers of a firm does not feel so much threatened by a firm's debt obligations, because they expect the debt will not be required by banks or will be paid by some other institution (e.g. state, for more see section 3)d) and therefore their bankruptcy risk premium associated with bonds is decreasing with softness of the budget constraint.

We can rewrite the equation (13) so that:

$$
\frac{P_{t+1}^{i, E}}{P}=\left(1+r_{t}^{i}\right) I_{t}^{i} c^{\prime}\left(q_{t}^{i^{*}}\right)+\underline{\eta_{i}^{t}}=\underbrace{\left(1+r_{t}^{f}\right) c^{\prime}\left(q_{t}^{i^{*}}\right)}_{M C_{-} \text {neoclassical. }} \underbrace{-\left[1+r_{t}^{f}-I_{t}^{i}\left(1+r_{t}^{i}\right)\right] c^{\prime}\left(q_{t}^{i^{*}}\right)}_{\text {discount_due_to_s } S B C}+\underline{\eta}_{\rightarrow}^{t} 0
$$

The equation (16) tells the following story. The first item on the right hand side is the classical present value of marginal costs of production (see equation 14). The second item shows how the value of costs is "discounted" via the soft budget constraint. It is negative and decreasing with the increase in the softness of the budget constraint. In an extreme case, when the firm has certainty, that it will not have to repay its debt $\left(I_{t}^{i}=0\right)$, the managers do not include the costs into their considerations about optimal output, because the first and second item clear each other. The third item, the bankruptcy risk premium, is falling towards zero.

As a result the second and third items together are negative for $I_{t}^{i}$ being significantly lower than unity. The supply of a firm facing soft budget constraint $\left(S_{B, i<1}^{i}\right)$ is therefore shifted to right and the optimal level of production $\left(q_{B, I<1}^{i}{ }^{*}\right)$ is higher than for a neoclassical risk neutral firm. Chart 7 illustrates graphically the analytical conclusions. 


\section{Chart 7. Risk behavior with soft budget constraint (i.e. $I<1$ )}

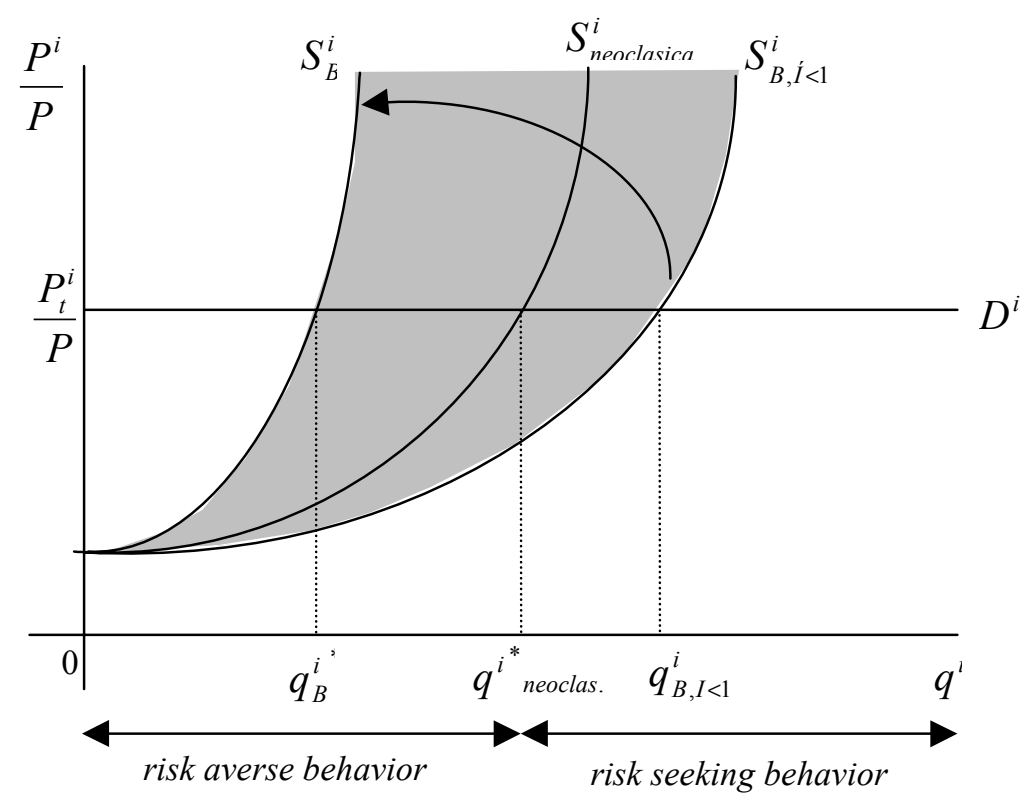

As we can see from the Chart 7 , through introducing the soft budget constraint we have broadened our model for risk-seeking behavior. In the environment of moral hazard caused by the possibility of not repaying the loans, the managers highly lever the firms and engage in risky production. The managers put higher weight to the favorable development of prices, because they are not so much motivated to reduce the chance of failure and as a result, a firm produces more even relative to the risk neutral producer.

In the market economies the soft budget constraint is usually not sustainable in the long run (Kornai, Maskin and Roland 2003). At the moment, when the degree of softness $I_{t}^{i}$ jumps to the unity the optimization issue changes rapidly (equation 15). A firm starts to face hard budget constraint and it causes substantial shrinkage in the production of a firm, because the firm's risk behavior with hard budget constraints goes on the same routes as we have drawn in the previous section. The change in $I_{t}^{i}$ is exogenous to our model, but it can be caused by e.g. privatization of state banks (see section 3)d).

\section{8) The determinants of firm's attitude to risk and optimal output decisions}

In this section we will elaborate on how the major parameters' of our model influence the firm's attitude to risk and its optimal output.

\section{a. Nominal net worth position and optimal output}

Firstly, we will analyze the impact of change in nominal net worth position on optimal output (i.e. supply of a firm) other things being equal and we will attempt to justify the following theoretical propositions resulting from our model. 
Result 1: Under price uncertainty stronger net worth position decreases the costs of production financing, decreases risk premium associated with bankruptcy and therefore, increases the optimal level of production.

Result 2: There is certain level of equity, above which the impact of increased equity has insignificant positive impact on optimal level of production.

When differentiating the optimality condition (equation 13) according to net worth position we get:

$$
0=\frac{\partial r_{t}^{i}}{\partial a_{t}^{i}} I_{t}^{i} c^{\prime}\left(q_{t}^{i^{*}}\right)+\left(1+r_{t}^{i}\right) I_{t}^{i} c^{\prime \prime}\left(q_{t}^{i^{*}}\right) \frac{\partial q_{t}^{i^{*}}}{\partial a_{t}^{i}}-\frac{\partial s_{t}^{i}}{\partial q_{t}^{i}} \frac{\partial r_{t}^{i}}{\partial a_{t}^{i}} I_{t}^{i}+\frac{\partial \eta_{t}^{i}}{\partial a_{t}^{i}}
$$

We can rewrite this equation so that:

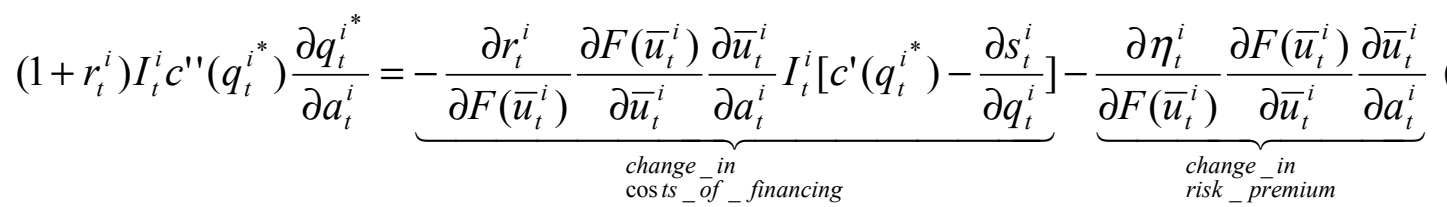

Let's see, why the right hand side of the equation (18) is always higher or equal to zero. The first item represents the change in costs of financing. The contractual interest rate required by banks is negatively dependent on the net worth position, because probability of bankruptcy decreases with higher net worth position (see section 5) and the sensitivity of probability of bankruptcy on different parameters) and the contractual interest increases with the probability of bankruptcy. As we assume that a firm can only partially finance its expansion through the issuance of new shares, the difference between marginal costs will be higher than the ability of firm to raise new shares. This difference is equal to the amount of debt, which is needed for financing additional unit of production. As only debt is connected with the contractual interest rate, the costs of financing will be decreasing with the net worth position and the whole first item on right hand side will be positive.

The second item, the change in the risk premium associated bankruptcy is also negatively dependent on the net worth position, because stronger net worth position decreases the probability of bankruptcy and lower probability of bankruptcy decreases risk premium. The second item is thus also positive. As we assume that marginal costs are increasing with quantity (A.4), the optimal output has to be increasing with net worth position (i.e. $\frac{\partial q_{t}^{i^{*}}}{\partial a_{t}^{i}} \geq 0$ ). This argumentation is related to the Result 1 .

In addition, the minimum of contractual interest rate is risk free interest rate (i.e. opportunity costs) and the minimum of risk premium is zero. Consequently, there is an upper limit of $a$ above which the decrease of interest rate and bankruptcy premium due to the increase in $a$ will be close to zero. This logic relates to the proposition 2 . 


\section{Chart 8. Net worth position and optimal output}

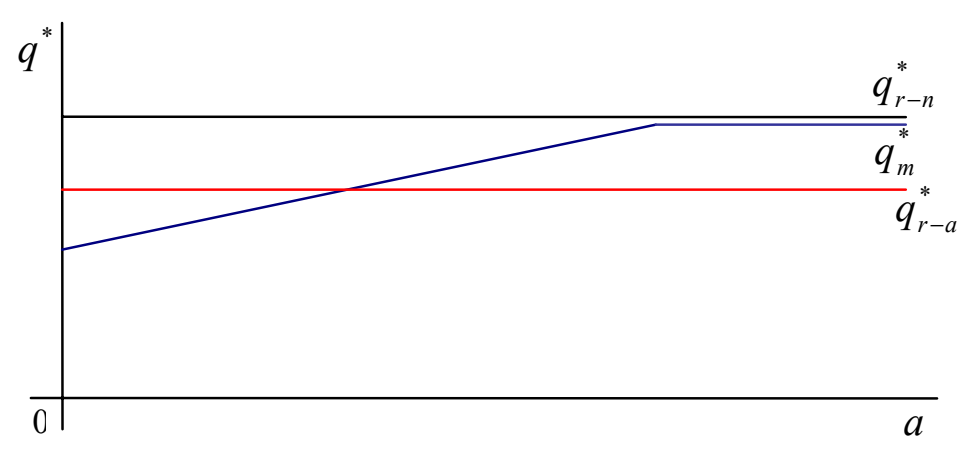

The Chart 8 illustrates the Result 1 and 2 and compares the impact of net worth position in our model with the impact in alternative concepts. The black line $q_{r-n}^{*}$ is the optimal output for neoclassical risk-neutral firm, which maximizes the expected value of profits. The red line $q_{r-a}^{*}$ illustrates the output for the normal model of firm under uncertainty (Sandmo, 1971), which maximizes the expected utility of owners, which are assumed to be risk averse. As a consequence the output is smaller than for risk neutral firm (section 3)). In both cases the output level is independent on the net worth position.

In contrary, the blue line $q_{m}^{*}$ represents optimal output for a firm in our model, which is codetermined by the net worth position. The exact position of $q_{m}^{*}$ line depends also on other variables, but in principle, the optimal level of output increases with $a$ (Result 1) until it reaches the level of production associated with risk neutral firm and then it remains constant (Result 2). The positive relationship between level of equity and level of production is concluded also in Greenwald and Stiglitz (1990, 1993a).

\section{b. Interest rate and optimal output}

Secondly, we will deal with the impact of a change in interest rates on the optimal output. As the contractual interest rate is determined by the equation (6), the only exogenous interest rate in our model is the risk-free interest rate.

Result 3: Under price uncertainty the increase of risk-free interest rate increases the costs of financing and increases the risk premium associated with bankruptcy and therefore, decreases the optimal level of production. Moreover, the optimal output decreases faster than for risk-neutral firm.

Proceeding in the same way as previously, we get the following condition after differentiating equation (13) according to risk-free interest rate:

$$
\left(1+r_{t}^{i}\right) I_{t}^{i} c^{\prime \prime}\left(q_{t}^{i^{*}}\right) \frac{\partial q_{t}^{i^{*}}}{\partial r_{t}^{f}}=-\frac{\partial r_{t}^{i}}{\partial r_{t}^{f}} I_{t}^{i}\left[c^{\prime}\left(q_{t}^{i^{*}}\right)-\frac{\partial s_{t}^{i}}{\partial q_{t}^{i}}\right]-\frac{\partial s_{t}^{i}}{\partial q_{t}^{i}}-\frac{\partial \eta_{t}^{i}}{\partial r_{t}^{i}} \frac{\partial r_{t}^{i}}{\partial r_{t}^{f}}
$$

The right hand side of the equation (19) is always negative. The contractual interest rate increases with the increase in the risk-free interest rate. The first and second item are thus negative, in other words costs of financing are increasing. The marginal bankruptcy costs of managers increase due to the increase in probability of bankruptcy resulting from the increase 
in risk-free interest rate. Hence the third item is negative. Therefore there is negative relationship between risk-free interest rate and optimal output $\left(\frac{\partial q_{t}^{i^{*}}}{\partial r_{t}^{f}} \leq 0\right)$.

\section{Chart 9. Interest rate and optimal output}

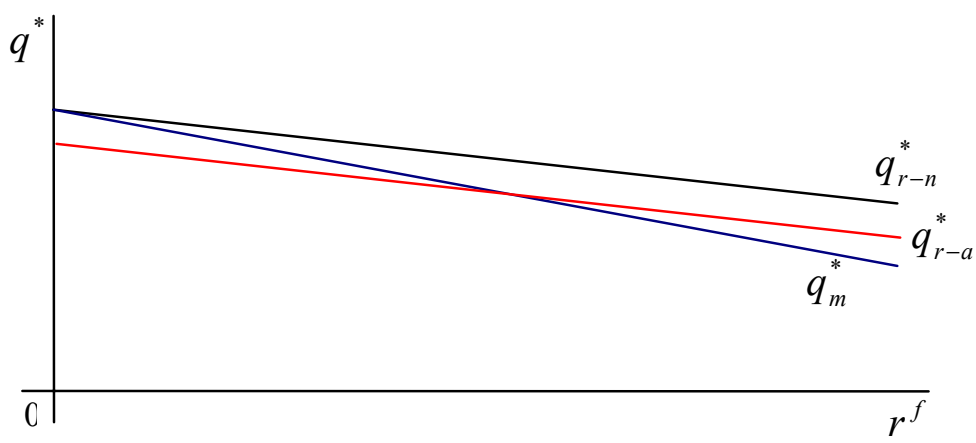

Let's compare the impact in various models. For traditional risk-neutral producer the decrease of output is determined by the increase of opportunity costs represented by risk-free interest rate (equation 13), whereas for a firm in our model, there are two effects: firstly increase in opportunity costs as for risk-neutral firm and secondly, the increase in risk premium required by managers. Therefore, for both producers the impact is negative, but in our model the effect is larger. For standard producer under uncertainty (Sandmo, 1971) the degree of risk aversion is exogenously given and thus independent on interest rate. The effect of increased interest rate will thus be the same as for risk-neutral producer.

\section{c. Sensitivity of managers on bankruptcy and optimal output}

Third, we will deal with effect of increased sensitivity of managers on bankruptcy $k$. This variable represents the aversion of managers towards bankruptcy, i.e. how big stigma they had to bear if a firm, which they manage, has to go to bankruptcy. It is therefore closely related to the socio-economical environment, in which a firm (resp. managers) operates and by the extent, to which the future prospects of managers are harmed by the bankruptcy.

Result 4: Under price uncertainty the increase of sensitivity of managers on bankruptcy increases the risk premium associated with bankruptcy and therefore, decreases the optimal level of production.

After differentiating the optimality condition, we get:

$\left(1+r_{t}^{i}\right) I_{t}^{i} c^{\prime \prime}\left(q_{t}^{i^{*}}\right) \frac{\partial q_{t}^{i^{*}}}{\partial k}=-\frac{\partial \eta_{t}^{i}}{\partial k}$

The logic is straightforward. The aversion of managers to bankruptcy does not influence the cost of financing as was the case for previous variables, but relates only to the risk premium "required" by managers. Using equation (11) we can see the risk premium is increasing in $k$. As we assume the marginal costs being increasing in quantity, the optimal output has to be decreasing in manager's sensitivity to bankruptcy $\left(\frac{\partial q_{t}^{i^{*}}}{\partial k} \leq 0\right)$. 


\section{Chart 10. Sensitivity of managers on bankruptcy and optimal output}

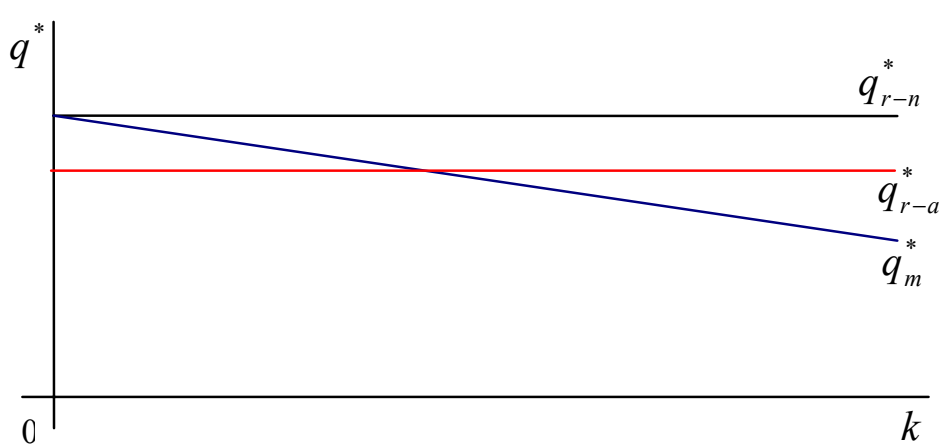

The Chart 10 captures the negative relationship between the optimal output and bankruptcy aversion of managers. This relationship is not present in the neoclassical theory of firm and standard theory of firm under uncertainty. In Greenwald and Stiglitz (1993a) this conclusion is not explicitly mentioned, although it is possible to derive it from their model.

\section{d. Financing through new shares and optimal output}

Forth, we will have a close look at the role of new shares in determining the behavior of a firm. We have briefly touched the importance of this variable in section 7)b when we were showing the connections between the existing theories of firm under uncertainty and the unifying nature of our model.

Result 5: Under price uncertainty the increase in financing through new shares decreases the costs of financing, decreases the risk premium associated with bankruptcy and therefore, increases the optimal level of production.

Result 6: There is certain level of new shares, above which the impact of financing through new shares has insignificant positive impact on optimal level of production.

After differentiation of equation (13), we get:

$\left(1+r_{t}^{i}\right) I_{t}^{i} c^{\prime \prime}\left(q_{t}^{i^{*}}\right) \frac{\partial q_{t}^{i^{*}}}{\partial s_{t}^{i}}=-\frac{\partial r_{t}^{i}}{\partial s_{t}^{i}} I_{t}^{i}\left[c^{\prime}\left(q_{t}^{i^{*}}\right)-\frac{\partial s_{t}^{i}}{\partial q_{t}^{i}}\right]-\frac{\partial \eta_{t}^{i}}{\partial s_{t}^{i}}$

The costs of financing are decreasing with the increase of new shares, because the probability of bankruptcy decreases and banks thus lower the required level of interest rate (equation 6). The contractual interest rate is decreasing towards the risk-free interest rate. The risk premium is also decreasing with the level of new shares and it has its limit equal to zero. Therefore, the

${ }^{14}$ There might be a slight confusion because of the notation in equation (21). The item $\frac{\partial s_{t}^{i}}{\partial q_{t}^{i}}$ is constant and as was defined earlier, it is the share of the costs of additional unit of production, which is financed by new equity. On the other hand $\frac{\partial q_{t}^{i^{*}}}{\partial s_{t}^{i}}$ represents the impact of new shares on optimal production. 
optimal level of production in positively dependent on the level of new shares, $\frac{\partial q_{t}^{i^{*}}}{\partial s_{t}^{i}} \geq 0$. The effects will be small for high levels of new shares.

This condition very much resembles the situation for the net worth position as one would intuitively expect. However, there is one important distinction. As was mentioned earlier net worth position $a_{t}^{i}$ represents the heritage, i.e. the sum of the past decisions of managers about financing and production levels, which turned out into profits or losses. On the other hand, new shares are targeted to the future. Unfortunately, the existing models (Greenwald and Stiglitz, 1990, 1993a) in this area do not give managers any space to decide between bonds and new equity shares. Therefore, there is now way for managers how to avoid full bond financing with maximum repayments obligations, maximum bankruptcy risk and lower levels of production.

In our model we abandon this restrictive assumption that $\frac{\partial s_{t}^{i}}{\partial q_{t}^{i}}=0$ and instead we assume, that a firm can be partially financed by new shares and in this way partially reduce the bond financing. The extent of new-shares-financing, above which there would have negative impact on market value, is exogenous and depends on the economic environment (e.g. the type of industry, degree to which capital market is matured or historical experience - path dependency).

\section{Chart 11. New shares and optimal output}

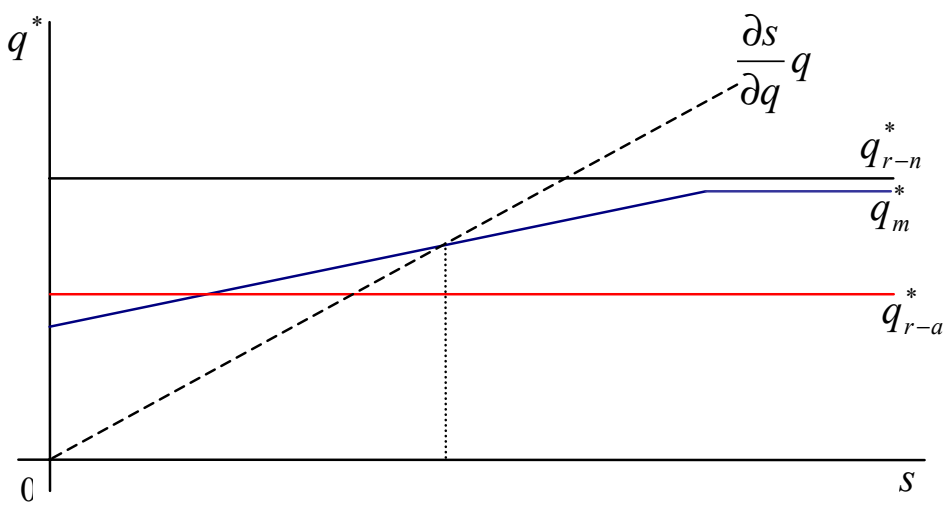

The Chart 11 illustrates these relationships and the independence of output on financing in theory of risk-neutral firm and theory of risk-averse firm (Sandmo, 1971). In our model, the optimal output is increasing up to the level of production associated with risk-neutral firm, above which it keeps basically constant. In the Chart 11 we have also included the financial constraint $\frac{\partial s}{\partial q}$ related to financing through new shares. The higher is this ratio (the line $\frac{\partial s}{\partial q} q$ rotates to the right) the higher is the level of production. We can easily see that if we take the extreme case used in the models of Greenwald and Stiglitz, where $\frac{\partial s}{\partial q}=0$ and thus $s=0$, the level of production under uncertainty will be the lowest possible. Their models thus work as a special case of our model as we have discussed already in section 7)b. 


\section{e. Degree of price uncertainty and optimal output}

Fifth, we may describe the marginal impact of price uncertainty, i.e. the effect of making a given distribution more risky. In section 5) we have defined the increase in price uncertainty as a "stretching" of the probability distribution around a constant mean and we have shown the slightly paradoxical impact of increased variance on the probability of bankruptcy.

The parameters or determinants we have analyzed so far influence first the solvency level of relative prices $\bar{u}$ and then through the probability of bankruptcy they usually change the contractual interest rate and the risk premium. This time we keep the solvency level constant and we model the impact of the changes in distribution function $\mathrm{F}($.$) . The change in the shape$ of distribution function is in fact another channel for changes of probability of bankruptcy.

It is not obvious how the increased variance can be formalized in the similar manner we have demonstrated the changes in firm's risk behavior for other parameters. Let's define subsidiary function $X(\bar{u}, \sigma)$. This function expresses the probability of bankruptcy, which depends not only on the solvency level of relative prices $\bar{u}$ as is the case of our $F(\bar{u})$, but also on the shape of the probability distribution, specifically on its variance. Probability of bankruptcy $F(\bar{u})$, which we have used so far, is based on distribution function, which has specified mean being equal to one and which has given constant variance $\sigma_{f}$.

In contrast, the subsidiary probability of bankruptcy $X(\bar{u}, \sigma)$ represents the value of the distribution function for different levels of $\bar{u}$ and different levels of uncertainty represented by $\sigma . X(\bar{u}, \sigma)$ has the same distribution function $\mathrm{F}($.$) , it has the same mean, but the variance$ is additional variable in comparison to $F(\bar{u})$. We can imagine the departure from $F(\bar{u})$ to $X(\bar{u}, \sigma)$ as adding another dimension $\sigma$. Therefore, $X\left(\bar{u}, \sigma_{f}\right)=F(\bar{u})$, if the "variable" variance in subsidiary probability of bankruptcy is the same as the given variance hidden in our original probability of bankruptcy.

Let's substitute the original probability of bankruptcy with the subsidiary one and let's differentiate the optimality condition (13) according uncertainty, which we have proxied by the variance. We get:

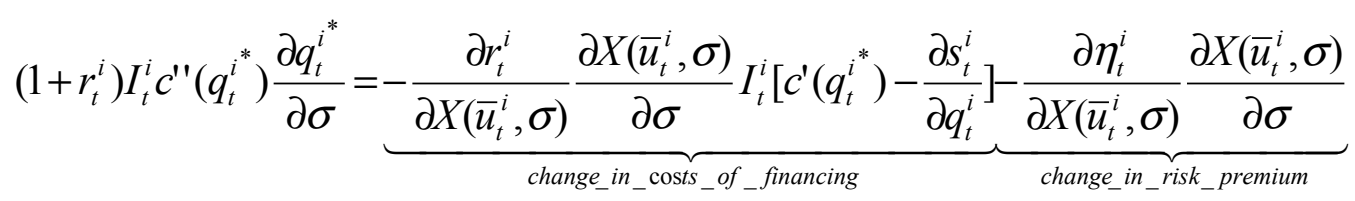

We can first look at the relationship between the increased uncertainty and the probability of bankruptcy $\left(\frac{\partial X\left(\bar{u}_{t}^{i}, \sigma\right)}{\partial \sigma}\right)$. We have already analyzed this relationship in section 5) (Chart 5) and we have concluded, that for firms, which expect to be solvent also after the uncertain output prices will be revealed, the increased variance increases the probability of bankruptcy. The inverse effect of uncertainty is present for firms facing high probability of bankruptcy. The probability of firm's survival is defined as one minus the probability of bankruptcy. Then if the probability of bankruptcy is higher than the probability of firm's survival (i.e. probability of bankruptcy is more than one half) the big variance of prices may rather help the firm out of troubles. 
Therefore, there is positive relationship between probability of bankruptcy and uncertainty $\left(\frac{\partial X\left(\bar{u}_{t}^{i}, \sigma\right)}{\partial \sigma}>0\right)$ if the firm's solvency level of relative prices is lower than one $(\bar{u}<1)$. The negative relationship is present $\frac{\partial X\left(\bar{u}_{t}^{i}, \sigma\right)}{\partial \sigma}<0$ if $\bar{u}>1$.

The remaining analysis of the equation (22) is similar to what we have done for other parameters. The increased probability of bankruptcy increases both, interest rate $\frac{\partial r_{t}^{i}}{\partial X\left(\bar{u}_{t}^{i}, \sigma\right)}>0$ and risk premium associated with bankruptcy $\frac{\partial \eta_{t}^{i}}{\partial X\left(\bar{u}_{t}^{i}, \sigma\right)}>0$. The overall impact of uncertainty on the optimal output $\frac{\partial q_{t}^{i^{*}}}{\partial \sigma}$ thus depends on the financial situation of the firm (i.e. the solvency level of relative prices $\bar{u}_{t}^{i}$ ).

Result 7: If the probability of bankruptcy is lower than the probability of the firm's survival, than the increase in the price uncertainty increases the costs of financing and the risk premium associated with bankruptcy and therefore, decreases the optimal level of production.

Result 8: If the probability of bankruptcy is higher than the probability of the firm's survival, than the increase in the price uncertainty increases the optimal level of production.

In other words, under normal circumstances, when firm will go bankrupt only in case of extremely adverse market conditions (low prices), the increased price uncertainty induces the firm to reduce its output level. On the other hand, if the firm has financial troubles and it is probable that it will have to leave the market unless something material happens, then the firm welcomes the increased uncertainty of its output prices and increases the optimal output in order to increase the chance that the firm will get of the troubles. In this situation the firm has an incentive to gamble way out of the coming insolvency by the risky investments and risky levels of production.

Let's compare. As the traditional risk-neutral firm does not take into account the changes in the price uncertainty, it does not change its optimal output and its supply $q_{r-n}^{*}$ is independent on the level of price uncertainty. The major departure of normal theories of firm under price uncertainty is their conclusion, that an increase in price uncertainty causes a decline in production $q_{r-a}^{*}$ due to the risk-averse nature of firm's decision-making.

Greenwald and Stiglitz's model (1993a) conclude the negative relationship between the degree of uncertainty and the optimal output as well. However, on other places Stiglitz (1994) points out on the incentives of insolvent banks to make high-risk loans in order to avoid insolvency and uses a similar logic we explained for the case of our firm. This phenomenon is theoretically explained also on number other places. For example Hlaváček (1999, pp. 106110) uses his model of firm, which maximizes the probability of its survival, and he argues that there are situations, which force the firm to behave in risk-seeking manner even though normally the firm would behave in risk averse manner. The immediate threat of firm's liquidation is taken as an example of such a situation. 


\section{Chart 12. Price uncertainty and optimal output ${ }^{15}$}

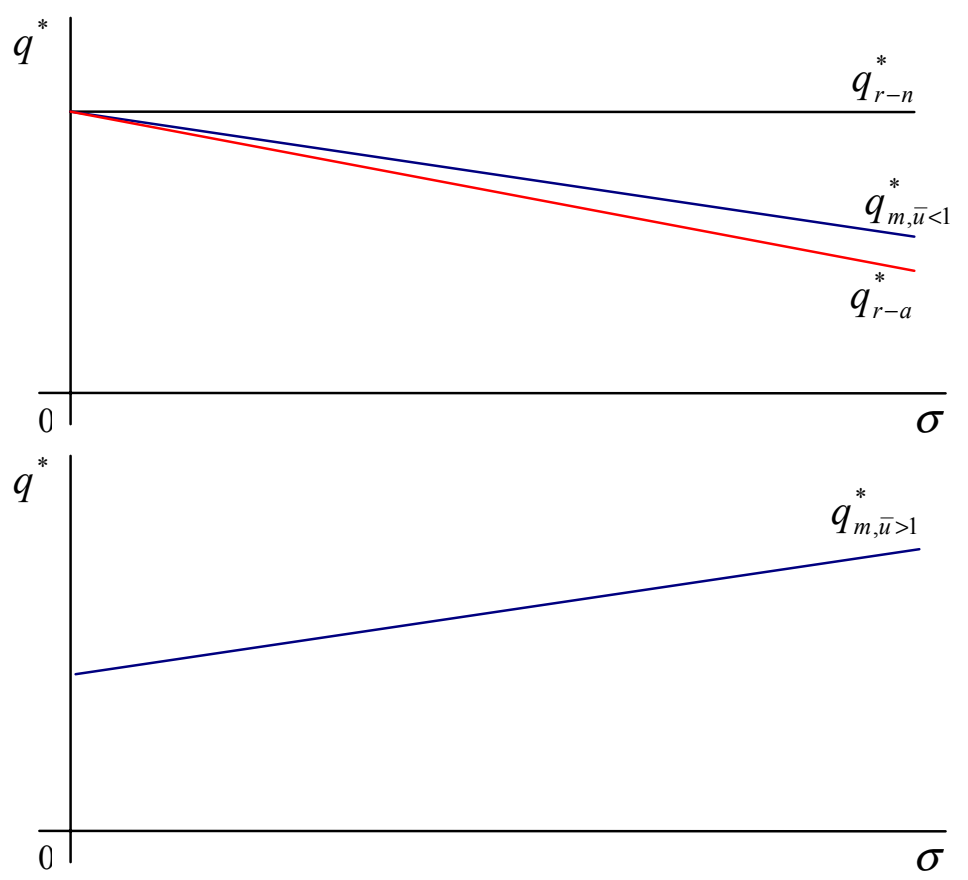

\section{f. Softness of the budget constraint and optimal output}

Sixth, we will analyze the impact of the soft budget constraint on optimal level of production, i.e. the situations when loans are offered to the financially troubled firms and when the repayment terms in loan contracts are relaxed.

Result 9: Under price uncertainty increase in the softness of the budget constraint decreases the costs of financing, decreases the risk premium associated with bankruptcy, discounts the value of debt perceived by managers and therefore, increases the optimal level of production.

$$
\left(1+r_{t}^{i}\right) I_{t}^{i} c^{\prime \prime}\left(q_{t}^{i^{*}}\right) \frac{\partial q_{t}^{i^{*}}}{\partial I_{t}^{i}}=\underbrace{-\frac{\partial r_{t}^{i}}{\partial I_{t}^{i}} I_{t}^{i}\left[c^{\prime}\left(q_{t}^{i^{*}}\right)-\frac{\partial s_{t}^{i}}{\partial q_{t}^{i}}\right]}_{\text {change_in_financing_costs }}-\underbrace{\frac{\partial \eta_{t}^{i}}{\partial I_{t}^{i}}}_{\begin{array}{c}
\text { change_in } \\
\text { risk_premium }
\end{array}} \underbrace{-\left(1+r_{t}^{i}\right)\left[c^{\prime}\left(q_{t}^{i^{*}}\right)-\frac{\partial s_{t}^{i}}{\partial q_{t}^{i}}\right]}_{\begin{array}{c}
\text { discount } \\
\text { due_s } S B \bar{C} \bar{C}_{-} M C
\end{array}}
$$

The impact of the soft budget constraint on firm behavior is slightly more complicated in comparison to other variables as we can see from the equation (23). There are two effects similar to preceding variables: the change in financing costs and the change in risk premium (first and second item on the right hand side). The contractual interest rate defined in equation 6 decreases with the degree of softness of the budget constraint and thus decreases the cost of financing. Softer budget constraint also decreases the threat for managers that a firm will go to bankruptcy (probability of bankruptcy) and therefore risk premium decreases as well.

${ }^{15}$ Although we plot $q_{r-a}^{*}$ steeper than $q_{m, \bar{u}<1}^{*}$ in the first chart, the sensitivities of optimal output on price uncertainty are not comparable. We show only the negative relationship for both cases. 
These two effects will push a firm to the level of production of risk-neutral firm (similarly as new shares and net worth position) ${ }^{16}$.

Moreover, in an environment of soft budget constraint managers "discount" the value of costs financed by debt, because they do not feel the necessity to fully repay the debt due to the relaxed repayment terms. This effect is represented by the third item, which is constantly negative. This third effect can push a firm into production levels even higher than for risk neutral firm and ex post this production expansion can be considered as excessively risky.

\section{Chart 13. Softness of the budget constraint and optimal output}

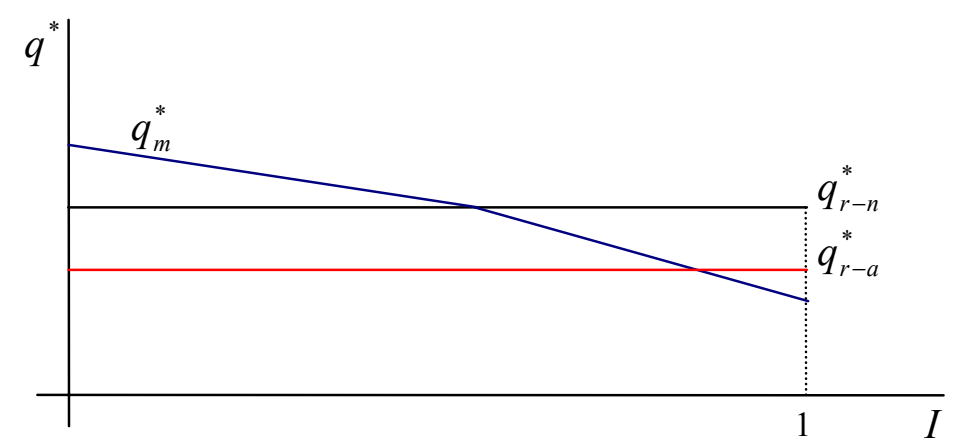

All three effects lead to the negative relationship between hardness of the budget constraint and optimal level of production $\left(\frac{\partial q_{t}^{i^{*}}}{\partial I_{t}^{i}} \leq 0\right)$. Chart 13 illustrates the logic graphically. The increase in optimal output $q_{m}^{*}$ is faster below the level of production of risk neutral firm, because all three effects are present. Above $q_{r-n}^{*}$ the output $q_{m}^{*}$ is growing in slower pace as only third effect (managers discount production costs financed by debt) is at work. Therefore, due to the soft budget constraint a firm can behave in risk-seeking manner. To the knowledge of the author, the risk-seeking behavior is not explainable in the framework of neither the standard theory of firm under uncertainty (Sandmo, 1971) nor by the New Keynesians (Greenwald and Stiglitz, 1993a). These theoretical streams have not attempted to incorporate the major insights of the soft budget constraint literature into their models.

\section{g. Summary}

The Table 2 below provides an at-the-first-glance comparison of the major Results of our model with the main benchmark concepts. The more detailed comparison we have done in the sections above. The sign " 1 " means that the given Result is possible to derive from the model, whereas " 0 " say that it is not present there.

${ }^{16}$ Although there certainly is a qualitative difference between the increase of output due to new shares or stronger net worth position vs. due to soft budget constraint, at this moment we omit the discussion, if this increased production is healthy and sustainable in the longer time horizon and we purely theoretically analyze the effects on output. 
Table 2. Comparison of Results of our model with alternative concepts

\begin{tabular}{|l|l|l|l|l|l|l|l|l|l|l|}
\hline & R. 1 & R. 2 & R. 3 & R. 4 & R. 5 & R. 6 & R. 7 & R. 8 & R. 9 \\
\hline & \multicolumn{2}{|c|}{ Net Worth } & $\begin{array}{c}\text { Interest } \\
\text { rate }\end{array}$ & $\begin{array}{l}\text { Bankrupt. } \\
\text { aversion }\end{array}$ & \multicolumn{2}{|c|}{ New Shares } & \multicolumn{2}{c|}{$\begin{array}{c}\text { Degree of } \\
\text { price } \\
\text { uncertainty }\end{array}$} & SBC \\
\hline $\begin{array}{l}\text { Neoclassical } \\
\text { firm }\end{array}$ & 0 & 0 & 1 & 0 & 0 & 0 & 0 & 0 & 0 \\
\hline $\begin{array}{l}\text { Sandmo } \\
(1971)\end{array}$ & 0 & 0 & 1 & 0 & 0 & 0 & 1 & 0 & 0 \\
\hline $\begin{array}{l}\text { Greenwald } \\
\text { and Stiglitz } \\
(1993 a)\end{array}$ & 1 & 1 & 1 & 1 & 0 & 0 & 1 & 0 & 0 \\
\hline $\begin{array}{l}\text { SBC, } \\
\text { Krugman } \\
(1998)\end{array}$ & 0 & 0 & 0 & 0 & 0 & 0 & 0 & 0 & 1 \\
\hline
\end{tabular}

It is important to say, that the Table 2 does not intend to imply that this model is better than the other ones. The most of results presented here are compatible with several alternative sets of assumptions about financial markets, investment opportunities and the structure of ownership. The concepts, which we have departed from, may provide more in-depth analysis on the specific issues they focus. But from the perspective of the question we have posed at the beginning of the paper they do not offer a complete picture.

\section{9) Conclusions}

In paper we have examined the risk behavior of competitive firm under price uncertainty. The aim was to find the answer for the question posed in the introduction: "What are the major determinants of the firm's attitude to risk and therefore of the firm's willingness to produce under uncertainty?" In doing so, we have used the following logical framework: financing $\rightarrow$ attitude to risk $\rightarrow$ optimal level of output.

We have developed a model of firm, where the managers are the primer decision-makers. In compliance with the approach of Greenwald and Stiglitz (1993a) we assume, that managers maximize the expected profit and in addition they associate personal costs with bankruptcy. This is due to the fact, that manager's reputation and value on the manager's market may be harmed due to bankruptcy.

Unique to our model is more general approach to the firm's financing possibilities and conditions. Our firm is not restricted to only debt-financing as is assumed in otherwise-veryinspiring model of Greenwald and Stiglitz (1993a), which implies risk averse behavior of firm and lower optimal output level. In our opinion, the story is more complex. Based on other theoretical concepts mostly from agency theory and soft budget constraint literature we have incorporated other plausible assumptions about firm's financing; most importantly: partial access to the equity market and possible existence of the soft budget constraint related to debtfinancing. This allowed us to formulate the conditions, under which the firm is induced to behave in more risk averse vs. risky manner.

Our model thus provides relatively very comprehensive endogeneisation of the firm's attitude to risk, which ranges from strongly risk averse behavior to risk seeking behavior and which to 
the extent of our knowledge is not present in the existing literature. The existing models of firm either assume the firm's attitude to risk (e.g. Sandmo, 1971), or focus on the explanation of certain type of attitude to risk; risk averse behavior is explained by e.g. Greenwald and Stiglitz (1993a) on one hand and risk seeking behavior enlightened by e.g. Krugman (1998) on the other hand. We have shown that from the perspective of our core question these concepts can be understood as special cases to the model developed above.

The attitude to risk directly influences the firm's willingness to produce in the environment of uncertainty. The presence of uncertainty thus changes many of the predictions of neoclassical theory of firm under certainty, where the only important determinants of firm's optimal output are technology and relative prices. Based on the results of our model we have devised nine propositions about the determinants of the firm's production behavior under uncertainty. Out of them the following considerations were found as the most interesting ones.

Firstly, firms with stronger net worth position and with more ready access to the equity market will tend to produce more other things being equal. The impact of these parameters is decreasing with their absolute value (i.e. output level is a concave function of these parameters) with maximum being at the level associated with the traditional neoclassical firm.

Secondly, the degree of price uncertainty (measured by mean-preserving changes in the variance of future prices) has dual effect depending on financial shape of the given firm. Under normal circumstances, when the probability of bankruptcy is relatively low, the increase in the price uncertainty will lead to the output reduction. On the other hand, the firm balancing at the verge of bankruptcy will be tempted by the increased uncertainty towards higher levels of production.

Thirdly, the soft budget constraint leads to the output expansion. The optimal output level of our firm facing soft budget constraint may get even above the neoclassical optimal output level. As we assume that in the market economy the soft budget constraint is not sustainable in the long run horizon, this behavior only creates short run production up-and-downs.

\section{Literature}

Akerlof, G.: The Market for Lemons: Qualitative Uncertainty and the Market Mechanism. Quarterly Journal of Economics, 1970, vol. 84, pp. 288-300.

Ackerlof, G. and Yellen, J.: A Near-Rational Model of the Business Cycle with Wage and Price Inertia. Quarterly Journal of Economics, 1985, vol. 100, pp. 823-838.

Bauer, M.: The Theory of Firm under Uncertainty: Financing, Attitude to Risk and Output Behavior. Prague, Diploma theses, Institute of Economic Studies, Charles University, 2005.

Coes, D.: Firm Output and Changes in Uncertainty. The American Economic Review, 1977, vol. 67, n. 2 , pp. 249-251.

Chambers, G. and Quiggin, J.: Uncertainty, Production, Choice and Agency: The StateContingent Approach. New York, Cambridge University Press 2000.

Davidson, P.: Is Probability Theory Relevant For Choice Under Uncertainty? A Post Keynesian Perspective, Journal of Economic Perspectives, winter 1991, vol. 5.

Dequech, D.: Uncertainty in a strong sense: meaning and sources. Economic issues, 1997, vol. 2. 
Dequech, D.: The New Institutional Economics and The Theory of Behavior under Uncertainty. Working paper of Institute of Economics, University of Campinas, Sao Paulo, 2001.

Dewatripont, M. and Maskin, E.: Credit and Efficiency in Centralized and Decentralized Economies. Review of Economic Studies, 1995, vol. 64, n.4, pp.541-555.

Djankov, S. and Murrel, P.: Enterprise Restructuring in Transition: A Quantitative Survey. Journal of Economic Literature, 2002, vol. 40, n.3, pp.739-792.

Dosi, G. and Edigi, M.: Substantive and procedural uncertainty - an exploration of economic behavior in changing environments. Journal of Evolutionary Economics, 1991, vol.1, pp. 145168.

Eaton, J., Gersovitz, M. and Stiglitz, J.E.: Pure Theory of Country Risk. European Economic Review, 1986, vol. 30, pp. 481-513.

Fama, E.: Agency problems and the theory of the firm. Journal of Political Economy, 1980, vol. 88 , pp. 288-307.

Fama, E. and Jensen, M.: Separation of ownership and control. Journal of Law and Economics, 1983, vol. 26, pp. 301-325.

Feder, G., Just, R.E., Schmitz, A.: Future Markets and the Theory of the Firm under Uncertainty. The Quarterly Journal of Economics, 1980, vol. 94, n.2, pp. 317-328.

Gravelle and Rees: Microeconomics. London, Longman 1992.

Greenwald, B.C. and Stiglitz, J.E.: Keynesian, New Keynesian and New Classical Economics. Oxford Economic Papers, 1987, vol. 39, pp. 119-132.

Greenwald, B. and Stiglitz, J.E.: Asymmetric Information and the New Theory of the Firm: Financial Constraints and Risk Behavior. The American Economic Review, 1990, vol. 80, n.2.

Greenwald, B.C. and Stiglitz, J.E.: Financial Market Imperfections and Business Cycles. The Quarterly Journal of Economics, 1993a, vol. 108, n.1, pp. 77-114.

Greenwald, B.C. and Stiglitz, J.E.: New and Old Keynesians. Journal of Economic Perspectives, 1993b, vol. 7, n.1, pp.23-44.

Grossmann, S. and Hart, O.: Corporate Financial Structure and Managerial Incentives. In McCall (ed.): The Economics of Information and Uncertainty. Chicago, Chicago University Press 1982.

Hau, A: Theory of the Firm Facing Uncertain Demand Revisited. Economic Theory, 2004, vol. 24, pp. 457-464.

Hawawini, G.: Uncertainty and the Production Decisions of the Owner-Managed and LaborManaged Firms. Oxford Economic Papers, 1984, vol. 36, n.1, pp. 119-130.

Hlaváček, J.: Mikroekonomie sounáležitosti se společenstvím. Prague, Karolinum 1999.

Holmstromm, B.R, and Tirole, J.: The Theory of the Firm. In: Schmalensee, R. and Willig, R.D. (eds.): Handbook of Industrial Organisation. Amsterdam, North-Holland 1989.

Jensen, M. and Meckling, W.: Theory of the Firm: Managerial Behavior, Agency Costs and Ownership Structure. Journal of Financial Economics, 1976, vol. 3, pp. 305-360.

Jensen, M.: Agency Costs of Free Cash Flow, Corporate Finance, and Takeovers. The American Economic review, 1986, vol.76, n.2, pp.323-329.

Knight, F.H: Risk, Uncertainty and Profit. Cambridge, Houghton Mifflin 1921. 
Kornai, J.: Resource-Constraint and Versus Demand-Constraint Systems. Econometrica, 1979, vol. 47, n. 4, pp.801-819.

Kornai, J., Maskin, E. and Roland, G.: Understanding the Soft Budget Constraint. Journal of Economic Literature, 2003, volume 41, n.4, pp. 1096-1136.

Krugman, P.: What Happened to Asia?, MIT 1998,

http://web.mit.edu/krugman/www/DISINTER.html.

Leland, H.: Theory of the Firm Facing Uncertain Demand. The American Economic Review, 1972, vol.62, pp. 278-291.

Machina, M: Dynamic Consistency and Non-expected Utility Models of Choice under Uncertainty. Journal of Economic Literature, 1989, vol. 27, n. 4, pp. 1622-68.

Magill, M. and Quinzii, M.: The Theory of Incomplete Markets. London, The MIT Press 1996.

Maskin, E. and Tirole, J.: Unforeseen Contingencies and Incomplete Contracts. Review of Economic Studies, 1999, vol. 66, pp.83-114.

Myers, S.C: The Capital Structure Puzzle. Journal of Finance, 1984, vol. 34, n. 3, pp. 575592.

Myers, S.C. and Majluf, N.S.: Corporate Financing and Investment Decisions When Firms Have Informations that Investors Do Not. Journal of Financial Economics, 1984, vol.11, pp.187-221.

Myers, S. C.: Capital structure. Journal of Economic Perspectives, vol. 15, 2001, pp. 81-102.

Muzundo, T.R.: On the Theory of the Competitive Labor-Managed Firm under Price Uncertainty. Journal of Comparative Economics, June 1979, pp. 127-144.

Quiggin, J.: Production under uncertainty and choice under uncertainty in the emergence of generalized expected utility theory. Theory and Decision, 2001, vol. 51, pp. 125-44.

Sandmo, A.: On the Theory of the Competitive Firm Under Price Uncertainty. American Economic Review, 1971, vol.61, pp. 65-73.

Schaffer, M. E.: Do firms in transition have soft budget constraint? A reconsideration of concepts and evidence. CERT Discussion Paper No. 97/20, 1998.

Schleifer, A. and Vishny, R.W.: Politicians and Firms. Quarterly Journal of Economics, 1994, vol. 109, n. 4, pp. 995-1025.

Stiglitz, J.E.: Whither Socialism?. Cambridge (MA), MIT Press 1994.

Williamson, O.: The Economic Institutions of Capitalism. New York, Free Press 1985.

Williamson, O.: Corporate Finance and Corporate Governance. Journal of Finance, 1987, vol. 43, No.3, pp. 567-591. 


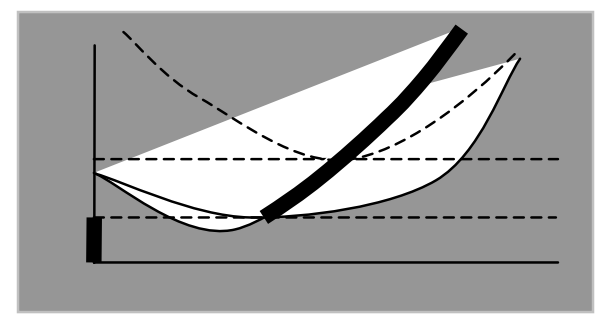

\section{Previously published :}

2001:

1. Michal Hlaváček: Modely difuze technologii

2. Tomáš Cahlik : Analýza ekonomického výzkumu

3. Vladimír Benáček: : Autentický soukromý sektor v transitivní ekonomice: příspěvek ke hledání kořenů a alternativ českého kapitalismu

4. Milan Sojka : Alternativni scénáře transformační strategie československé ekonomiky na počátku 90. let a jejich teoretická východiska

5. Jiři Hlaváček, Michal Hlaváček: Optimum výrobce v odvětvís nikdy neklesajícími výnosy z rozsahu

6. František Turnovec: The Czech Republic on its Way to the European Union

7. Lubomír Mlčoch : Ekonomie dìvěry

8. Luděk Urban : Zásady společné obchodni politiky a důsledky jejich přijetí pro českou ekonomiku

9. Jan Ámos Víšek: Export z $\check{C} R$ do EU a mimo EU

10. Miloslav S. Vošvrda: On Martingale Diffusions in Financial Markets

11. František Turnovec :Flexible Integration and the Excessive Deficit Procedure in the EMU

12. Jiři Hlaváček, Michal Hlaváček: Byl proces eliminace podniků ozdravnou procedurou pro české hospodárstvi konce 90. let?

13. Karel Půlpán: Hospodářský vývoj Španělska jako inspirace pro Českou republiku.

14. Jiři Hlaváček, Michal Hlaváček: Ekonomicky racionální altruismus

15. Jiři Kameníček: Nástroje pro popis nestandardního ekonomického chování, aplikace teorie lidského kapitálu

16. Jiři Hlaváček: Redistribuce : projev lidských preferencí a společenských potřeb

17. Silvester van Koten: Transaction Cost Economics: Basic Concepts and Extensions

18. Hlaváček J., Hlaváček M.: Ekonomická racionalita donátora a di̊věra k př́jemci dotace

2002:

19. Vladimír Benáček, Višek Jan Ámos: Determining Factors of Competitiveness of Trade and Specialization of Czech Industrial Sector before the EU Accession

20. Milan Sojka, Postkeynesovská teorie peněz, peněžní a úvěrová politika a postavení centrální banky

21. Milan Sojka, Alternativni scénáre transformační strategie československé ekonomiky na počátku 90. let a jejich teoretická východiska

22. František Turnovec, Economic Research and Education in the Czech Republic 1989-2000

23. Jiř́ Hlaváček, Michal Hlaváček: Petrohradský paradox

24. František Turnovec : Evaluation of National, Political and Institutional Influence in Consultation, Cooperation and Co-decision Procedures of the EU Decision Making

25. Karel Půlpán: Rakouský poválečný vývoj

2003:

26. Ondřej Schneider : European Pension Systems and the EU Enlargement

27. Martin Gregor: Mancur Olson redivivus, ,Vzestup a pád národü“ a současné společenské vědy”

28. Martin Gregor: Mancur Olson's Addendum to New Keynesianism: Wage Stickiness Explained

29. Patrik Nový : Olsonova teorie hospodářského cyklu ve světle empirie: návrh alternativního metodologického prístupu

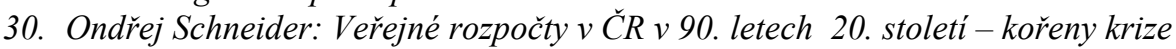

31. Michal Ježek: Mikroanalýza reformy českého důchodového systému

32. Michal Hlaváček: Efektivnost pořizení a předávání informace mezi privátními subjekty s pozitivněextenalitní vazbou

33. Tomáš Richter: Zástavní právo $k$ podniku z pohledu teorie a praxe dluhového financování

34. Vladimír Benáček: Rise of an Authentic Private Sector in an Economy of Transition: De Novo Enterprises and their Impact on the Czech Economy

35. Tomáš Cahlík, Soňa Pokutová, Ctirad Slavik: Human Capital Mobility

36. Tomáš Cahlík, Jakub Sovina: Konvergence a soutěžní výhody ČR

37. Ondřej Schneider, Petr Hedbávný: Fiscal Policy: Too Political? 
38. Jiři Havel: Akcionářská demokracie „Czech made“

39. Jiř́ Hlaváček, Michal Hlaváček: K mikroekonomickému klimatu v ČR na začátku 21.století: kartel prodejcủ pohonných hmot? (připadová studie)

40. Karel Janda: Credit Guarantees in a Credit Market with Adverse Selection

41. Lubomir Mlčoch: Společné dobro pro ekonomiku: národni, evropské, globální

42. Karel Půlpán: Hospodářský vývoj Německa jako inspirace pro Česko

43. Milan Sojka: Czech Transformation Strategy and its Economic Consequences: A Case of an Institutional Failure

44. Luděk Urban: Lisabonská strategie, jeji hlavni směry a nástroje.

2004:

45. Jiři Hlaváček, Michal Hlaváček: Models of Economically Rational Donators

46. Karel Kouba, Ondřej Vychodil, Jitka Roberts: Privatizace bez kapitálu.

47. František Turnovec: Economic Research in the Czech Republic: Entering International Academic Marke.t

48. František Turnovec, Jacek W. Mercik, Mariusz Mazurkiewicz: Power Indices: Shapley-Shubik or PenroseBanzhaf?

49. Vladimír Benáček: Current Account Developments in Central, Baltic and South-Eastern Europe in the Preenlargement Period in 2002-2003

50. Vladimír Benáček: External FInancing and FDI in Central, Baltic and South-Eastern Europe during 20022003

51. Tomáš Cahlikk, Soňa Pokutová, Ctirad Slavik: Human Capital Mobility II

52. Karel Diviš, Petr Teplý: Informační efektivnost burzovních trhů ve střední Evropě

53. František Turnovec: Česká ekonomická věda na mezinárodním akademickém trhu: měřní vědeckého kapitálu vysokoškolských a dalšich výzkumných pracovišt'

54. Karel Půlpán: Měnové plánování za reálného socialismu

55. Petr Hedbávný, Ondřej Schneider, Jan Zápal: Does the Enlarged European Union Need a Better Fiscal Pact?

56. Martin Gregor: Governing Fiscal Commons in the Enlarged European Union.

57. Michal Mejstř́k: Privatizace, regulace a deregulace utilit v EU a ČR: očekávání a fakta

58. Ilona Bažantová: České centrální bankovnictví po vstup České republiky do Evropské unie (právně institucionální pohled)

59. Jiři Havel: Dilemata českého dozoru finančních trhů.

60. Irena Jindřichovská: Response of Regulatory Bodies to FInancial Crises: Role of Auditors and International Comparison

61. Karel Janda: Bankruptcy Procedures with Ex Post Moral Hazard

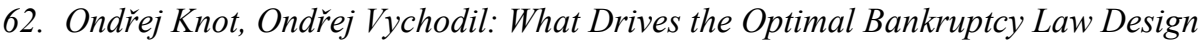

63. Jiři Hlaváček, Michal Hlaváček: Models of Economically Rational Donators: Altruism Can Be Cruel

64. Alě̌ Bulǐr, Kateřina Šmídková: Would Fast Sailing towards the Euro Be Smooth? What Fundamental Real Exchange Rates Tell Us about Acceding Economies?

65. Gabriela Hrubá: Rozložení daňového břemene mezi české domácnosti: přimé daně

66. Gabriela Hrubá: Rozložení daňového břemene mezi české domácnosti: nepř́mé daně

67. Ondřej Schneider, Tomáš Jelinek: Distributive Impact of Czech Social Security and Tax Systems: Dynamics in Early 2000's.

68. Ondrej Schneider: Who Pays Taxes and Who Gets Benefits in the Czech Republic.

2005:

69. František Turnovec: New Measure of Voting Power

70. František Turnovec:Arithmetic of Propoerty Rights: A Leontief-type Model of Ownership Structures

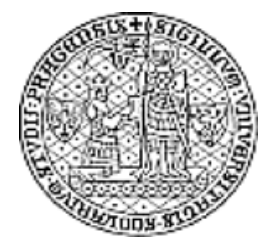

Univerzita Karlova v Praze, Fakulta sociálních věd,

Institut ekonomických studií [UK FSV - IES] Praha 1, Opletalova 26.

E-mail :ies@mbox.fsv.cuni.cz

http://ies.fsv.cuni.cz 